\title{
Age and isotopic fingerprints of some plutonic rocks in the Wiborg rapakivi granite batholith with special reference to the dark wiborgite of the Ristisaari Island
}

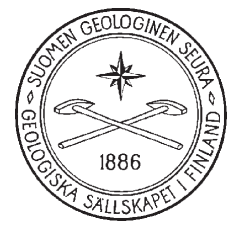

\author{
O.T. RÄMÖ ${ }^{1)^{*}}$, V. TURKKI ${ }^{2)}$, I. MÄNTTÄRI ${ }^{3)}$, A. HeINONEN ${ }^{1)}$, \\ K. LARJAMO ${ }^{1)}$ AND Y. LAHAYE ${ }^{4)}$ \\ 1) Department of Geosciences and Geography, Division of Geology, \\ P.O. Box 64, FI-00014 University of Helsinki, Finland \\ 2) Rässintie 12, FI-47200 Elimöki, Finland \\ 3) Geological Survey of Finland, P.O. Box 96, FI-02150 Espoo, Finland \\ 4) The National SGL Laboratory, clo Geological Survey of Finland, \\ P.O. Box 96, FI-02150 Espoo, Finland
}

\section{Abstract}

The mid-Proterozoic, locus classicus Wiborg rapakivi granite batholith of southeastern Finland and adjacent Russia comprises a varying, bimodal (silicic-basic) sequence of plutonic, subvolcanic, and volcanic rocks. At the current level of erosion silicic rocks are dominant, the most prominent of which are wiborgites and dark wiborgites (that have been considered to mark the main build-up stage of the batholith) and pyterlites. New observations and optical microscopy data from the dark wiborgite-dominated Ristisaari Island in the southern, off-shore part of the Wiborg batholith show that dark plagioclase megacrysts in dark wiborgite are calcic xenocrysts. They were probably incorporated into wiborgite magma from consanguineous massiftype anorthosite magmas in the course of the evolution of the bimodal magmatic system. Our new ID-TIMS U-Pb zircon age of the Ristisaari Island dark wiborgite, $1627 \pm 3 \mathrm{Ma}$, is the youngest isotopic age so far determined for the plutonic rocks of the Wiborg batholith. This, combined with preexisting U-Pb zircon data, implies a minimum duration of 12 m.y. (1642-1630 $\mathrm{Ma}$ ) for the emplacement of the plutonic rocks of the batholith. Combined with data on highlevel dike rocks, a window of at least 20 m.y. (1642-1622 Ma) is implied. Furthermore, as the batholith grew, the overall locus of magmatism may have shifted southwards. New whole-rock $\mathrm{Nd}$ isotope data on the dark wiborgite of the Ristisaari Island and three further granites of the batholith, as well as Nd (whole-rock) and Sr (whole-rock, plagioclase) isotope data on a spectrolite massif-type anorthosite from the east-central part of the batholith, are also presented. These data suggest that the lithosphere across the Wiborg batholith area in the southeastern part of the Svecofennian orogen may vary slightly in overall mantle separation age.

Keywords (GeoRef Thesaurus, AGI): granites, rapakivi, anorthosite, geochemistry, isotopes, absolute age, U/Pb, Sm/Nd, Rb/Sr, zircon, Proterozoic, Ristisaari Island, Finland

*Corresponding author (e-mail: tapani.ramo@helsinki.fi)

Editorial handling: Jussi S. Heinonen (jussi.s.heinonen@helsinki.fi) 


\section{Introduction}

The type locality of the Proterozoic rapakivi granites, the Wiborg batholith of southeastern Finland and adjacent far west Russia, comprises a versatile series of granitic plutonic rocks. These granites are A-type (cf. Bonin, 2007; Dall'Agnol et al., 2012) and they are associated with coeval leucogabbroic (leucogabbronoritic) rocks of the massif-type anorthosite clan (Alviola et al., 1999; cf. Ashwal, 1993), subvolcanic dikes (both mafic and silicic), and rare lavas (basalt, rhyolite) and fragmentary volcanic rocks (e.g., Haapala \& Rämö, 1990; Andersson \& Eklund, 1994; Rämö \& Haapala, 1995, 2005; Eklund et al., 1996; Rämö et al., 2010). Reconnaissance bedrock mapping of the Wiborg batholith in the 1960s and 1970s showed that the bulk $(-75 \%)$ of the currently exposed $\sim 18000 \mathrm{~km}^{2}$ Finnish part of the batholith consist of wiborgite, the rapakivi granite proper (Simonen \& Vorma, 1969; Simonen, 1987; Fig. 1). The wiborgite is characterized by ovoid alkali feldspar megacrysts mantled by sodic plagioclase, sodic plagioclase phenocrysts, two generations of magmatic quartz (early and late) as well as high-Fe/Mg silicates (fayalite, hastingsite, annite) that are typically found in the interstices of early formed feldspar and quartz (Fig. 2a).

The second most abundant rock type $(-6 \%)$ is pyterlite (the majority of alkali feldspar megacrysts not mantled by plagioclase, hastingsite subordinate to annite) and the third $(-5 \%)$ the so-called dark (or dark-coloured) wiborgite (Vorma, 1971; see also Wahl, 1925). The dark wiborgite differs from wiborgite by the amount of alkali feldspar megacrysts (in general, more abundant in the latter) and the presence of dark-gray and black plagioclase megacrysts (Fig. 2b). Dark wiborgite forms relatively large areas within the wiborgite, particularly in the western part of the batholith, where it is found as two large $(-10$ by $20 \mathrm{~km})$ and several smaller plutonic bodies within wiborgite (Fig. 1). Lithologic observations from the southern, off-shore part of batholith are confined to relatively sparse islands and skerries; these show, however, that the southernmost part of the batholith is governed by dark wiborgite and other relatively mafic rapakivi granite types (Simonen, 1987). The mutual relationships (intrusion sequence, possible magmatic consanguineity) of wiborgite and dark wiborgite are not fully understood.

We have studied a dark wiborgite from the Ristisaari Island in the western segment of the archipelago part of the Wiborg batholith (Fig. 1). Here we summarize unpublished results of a bedrock mapping project recently carried out on the island (Turkki, 2005) and expand on the mineralogical significance (dark plagioclase megacrysts vs. plagioclase phenocrysts and plagioclase rims around alkali feldspar megacrysts) of dark wiborgite. We report a multigrain $\mathrm{U}-\mathrm{Pb}$ zircon age and whole-rock $\mathrm{Nd}$ isotope composition for the dark wiborgite of Ristisaari as well as new whole-rock $\mathrm{Nd}$ isotope data on two previously dated granite samples from the Finnish mainland part of the Wiborg batholith: a biotite granite from Verla (northwestern part of the batholith) and a dark rapakivi granite from Ylijärvi (east-central part of the batholith). In addition, whole-rock (ID-TIMS) and in situ plagioclase (laser ablation MC-ICP-MS) Sr isotope compositions of a spectrolite olivine leucogabbronorite from the Ylijärvi region are presented. We compare these data to published $\mathrm{U}-\mathrm{Pb}$ zircon ages and isotope compositions of the lithologic units of the classic Wiborg batholith and beyond, and use them to shed new light on the lithologic assemblage, emplacement history, and magmatic evolution of the batholith.

\section{Geologic setting and sample description}

The Ristisaari Island is located at the northern border of the zone of dark wiborgite in the southern part of the batholith. The island is roughly equant in shape, $1-1.5 \mathrm{~km}$ in diameter, and hosts superb, glacially polished shoreline exposures of rapakivi granite (Fig. 3). Most of the island consists of dark wiborgite (Fig. 4). The Ristisaari dark wiborgite is a coarse-grained, coarse-porphyritic hastingsite \pm fayalite granite with ovoidal alkali feldspar megacrysts and plagioclase megacrysts (Turkki, 


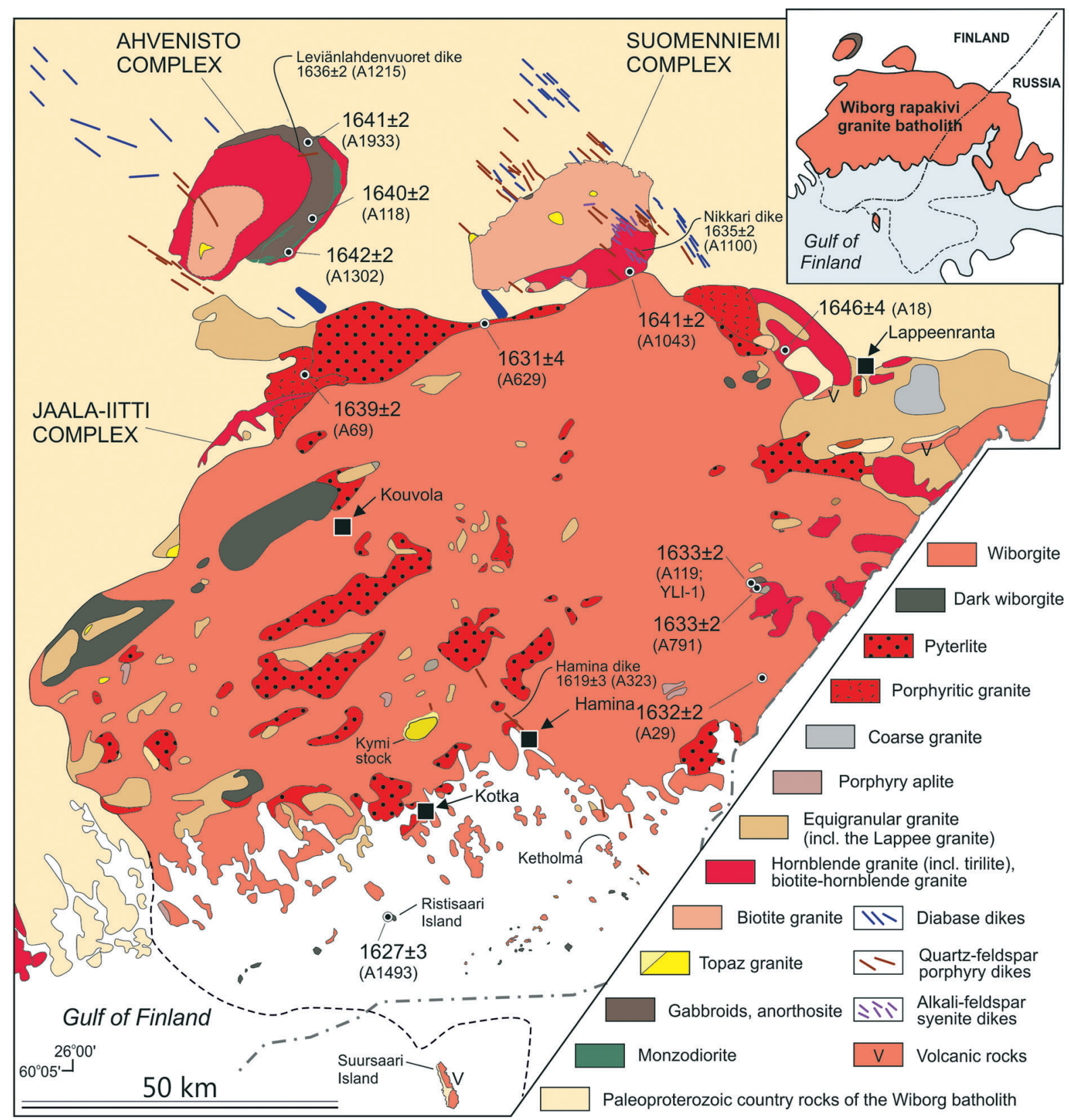

Fig. 1. Geological map of the Finnish part of the Wiborg rapakivi granite batholith showing the distribution of the main types of plutonic, subvolcanic, and volcanic rocks. Samples with the most accurate U-Pb zircon ages (in the northern, eastern, and southern parts of the batholith; Fig. 9) are shown, as are the locations of the Ketholma wiborgite (Fig. 2a), three quartz-feldspar porphyry dikes (Leviänlahdenvuoret, Nikkari, Hamina), and the Kymi topaz granite cupola. Key to the plutonic samples: A18 Värtö tirilite, A29 Muurikkala wiborgite, A69 Verla biotite granite, A118 Nurmaa leucogabbronorite, A119 Ylijärvi spectrolite olivine leucogabbronorite, A629 Parola pyterlite, A791 Ylijärvi dark rapakivi granite, A1043 Pohjalampi hornblende granite, A1302 Paljakka quartz monzodiorite, A1493 Ristisaari dark wiborgite, A1933 Pitkäjärvi anorthosite. Major Finnish towns are indicated with arrows. Dashed line marks the purported extent of the batholith in the eastern Gulf of Finland area, gray dot-dashed line is the national border. Inset shows map area relative to the entire Wiborg batholith. Compiled from Rämö and Haapala (2005), Salonsaari (1995), Lukkari (2007), Rämö et al. (2010), and Cook et al. (2011). 
2005). The former are typically $2-10 \mathrm{~cm}$ in diameter and mantled by sodic plagioclase; the largest alkali feldspar megacrysts tend to be unmantled, however. The plagioclase megacrysts are dark-gray to black, euhedral, up to $-9 \mathrm{~cm}$ long and $-5 \mathrm{~cm}$ wide, and more calcic than plagioclase mantling alkali feldspar ovoids and plagioclase phenocrysts in the dark wiborgite (cf. Fig. 2b; Section 5.1.).

Fayalite-bearing melagranite dikes are found to cut the Ristisaari dark wiborgite at several locations across the island. In the southern tip of the island, at Lounatlahti (Fig. 4), one such dike is well exposed. The dike is $26 \mathrm{~m}$ long and $2 \mathrm{~m}$ wide on average, has relatively sharp contacts against the surrounding dark wiborgite, and is characterized by schlieren (see also Simonen, 1961). According to Turkki (2005), the dike is rather heterogeneous with relatively rare angular andesine-labradorite megacrysts in a medium-grained granitic matrix with 36-39 vol.\% alkali feldspar, 20-23 vol.\% quartz, 15-19 vol.\%
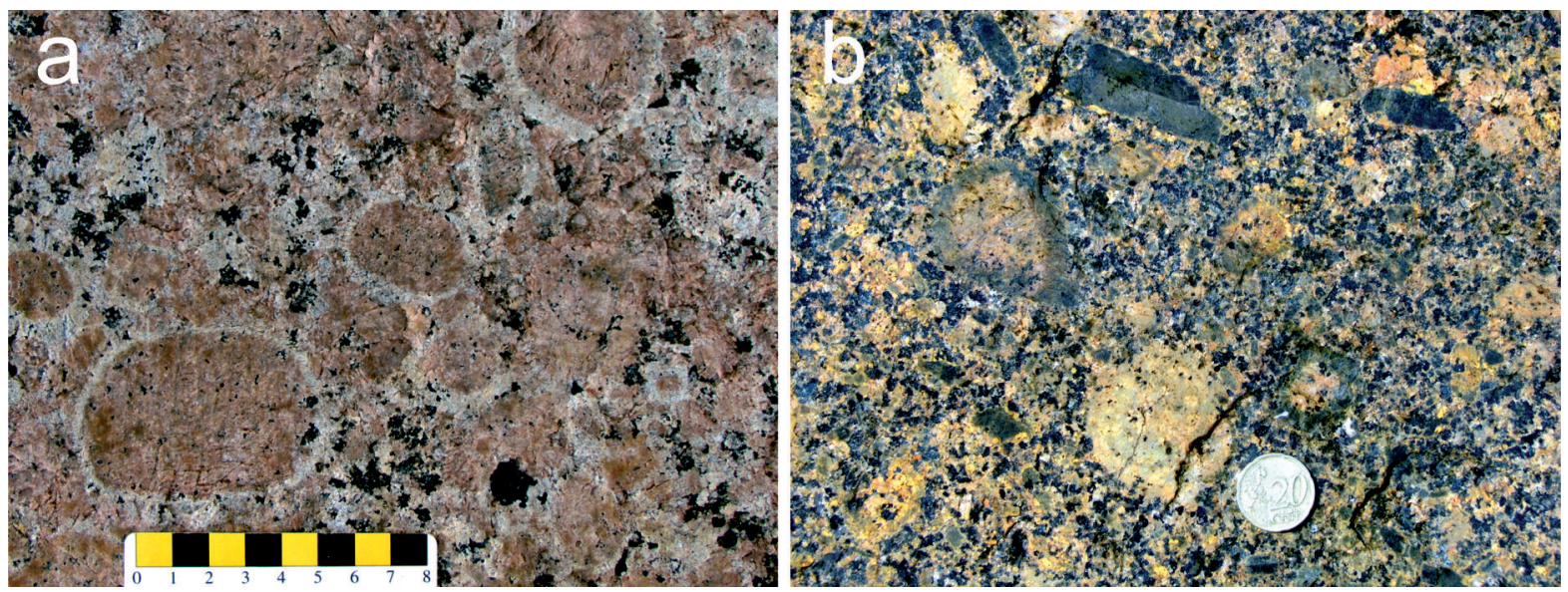

Fig. 2. Photographs of the two main types of wiborgite in the Wiborg batholith at identical scales. a) Regular wiborgite from Ketholma (Tammio Island) in the Hamina archipelago (Fig. 1), with sodic plagioclase weathered pale gray. Scale bar is in $\mathrm{cm}$. b) Dark wiborgite from the Ristisaari Island in the Kotka archipelago (Figs. 1, 4). Dark plagioclase megacrysts are evident in the upper part of the photograph; these differ from the green, more sodic plagioclase that mantles some of the alkali feldspar megacrysts (yellow) and is also present as phenocrysts in the groundmass. Diameter of the coin is $2.2 \mathrm{~cm}$. Photographs by the first author.

Fig. 3. Photograph from the southwestern shore (Lounainen kallio; Fig. 4) of the Ristisaari Island towards southsoutheast. Glacially polished outcrops of dark wiborgite with twinkling alkali feldspar megacryst in the foreground. The skyline at $23 \mathrm{~km}$ is governed by the paleovolcanic Suursaari Island (eastern Gulf of Finland, Russia; Fig. 1), where rapakivi granite-related volcanic rocks ( 1635 Ma; Levchenkov et al., 1998; Rämö et al., 2007) and a basal quartz arenitic conglomerate (maximum depositional age 1650 Ma; Pokki et al., 2013) are preserved from erosion (presumably in a down-faulted crustal block) and lie unconformably atop Svecofennian metamorphic bedrock. Photograph by the first author.

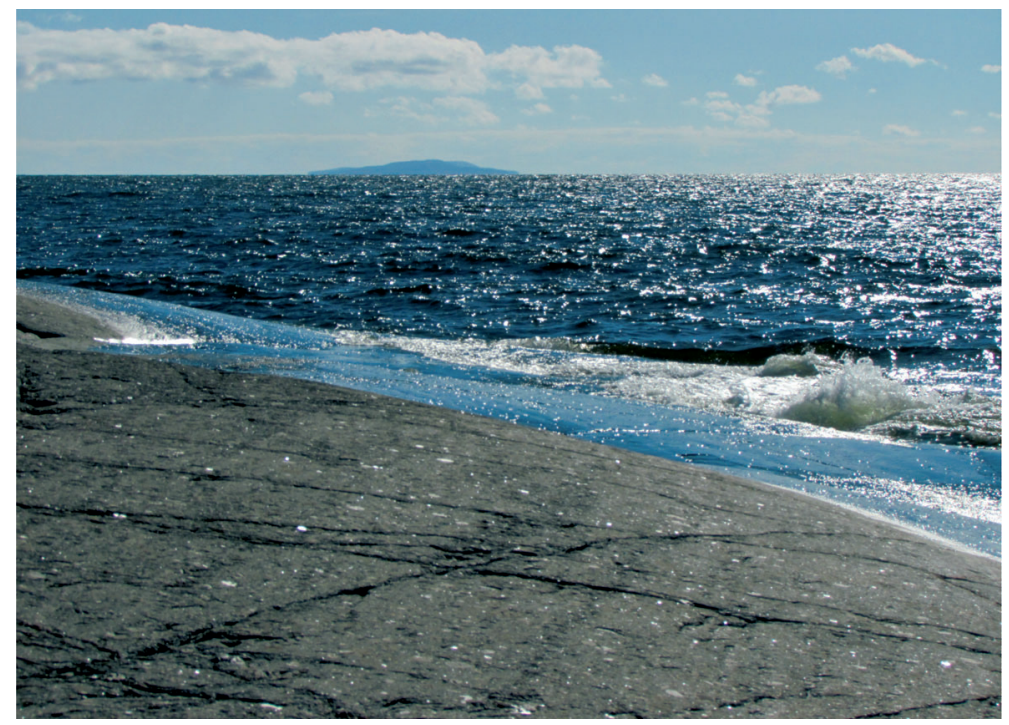


hastingsitic hornblende, $13-18$ vol.\% sodic plagioclase, 4-5 vol.\% fayalite, $1-3$ vol.\% biotite, and 1 vol.\% oxide (as well as trace amounts of apatite, fluorite, and zircon); hornblende is characteristically interstitial (oikocrystic).

On the northeastern shore of the island (cf. Fig. 4), dark wiborgite is in contact with several plutonic varieties of the granitic spectrum of the Finnish rapakivi association (Turkki, 2005). This location marks the northern extent of the southern dark wiborgite zone at this longitude (Fig. 1; see also Vorma, 1971; Rämö et al., 2010). These rock types comprise (1) a wiborgite with densely packed alkali feldspar ovoids (but no basic plagioclase xenocrysts); (2) a sparsely porphyritic rapakivi granite characterized by scattered oligoclase-mantled alkali feldspar ovoids; (3) a tirilitic (relatively mafic) medium-grained, equigranular rapakivi granite; and (4) a medium-grained, equigranular biotite granite. Most of these rock types have sharp mutual contacts.
Our dark wiborgite sample for isotopic studies (sample A1493; field station OTR-96-5) was taken on June $2^{\text {nd }}, 1996$ from the northwestern shore of the island at Tapaninkallio at a WWII coastal artillery bunker site ( $\mathrm{N} \mathrm{60}{ }^{\circ} 18.817^{\prime}$, E 26 ${ }^{\circ} 48.088^{\prime}$; WGS84). The sample is a typical dark wiborgite with sparse ovoidal alkali feldspar megacrysts (mantled and unmantled) up to $8 \mathrm{~cm}$ in diameter as well as up to $6 \mathrm{~cm}$ long, dark tabular plagioclase megacrysts. The Verla porphyritic biotite granite sample (A69) comes from a relatively large $(\varnothing-10$ $\mathrm{km}$ ) body of porphyritic rapakivi granite on the northwestern flank of the Wiborg batholith (Fig. 1; Vaasjoki \& Rämö, 1989; Vaasjoki et al., 1991). The dark (tirilitic) rapakivi granite (A791) and spectrolite olivine leucogabbronorite (A119, YLI1) were sampled in the Ylijärvi area in the eastcentral part of the batholith where a cluster of small (maximum dimensions 1 by $2 \mathrm{~km}$ at current erosion level) massif-type anorthosite bodies are found

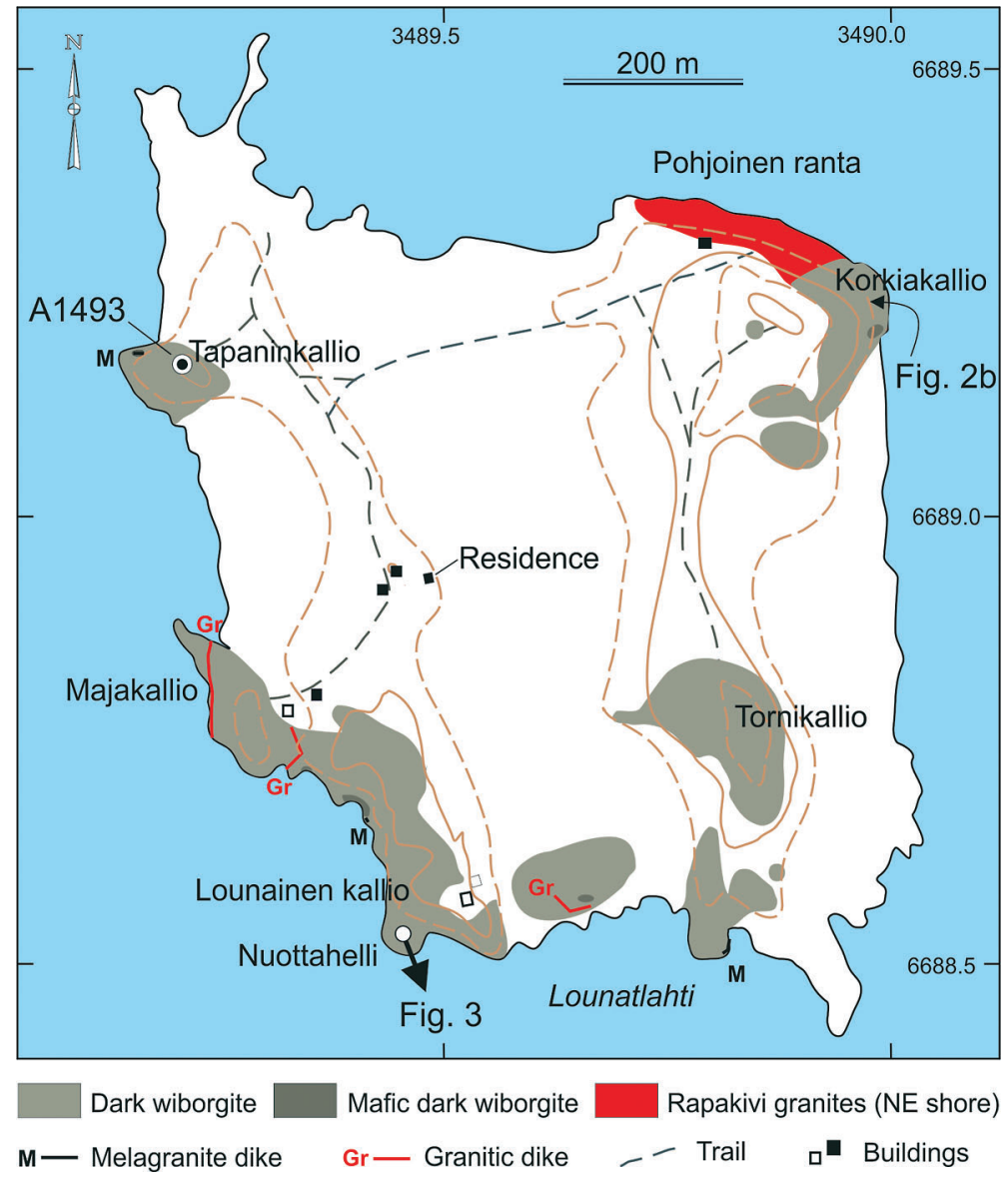

Fig. 4. Map of the Ristisaari Island showing the distribution of bedrock outcrops (in color) and the main rock types of the island. Location of the U-Pb age sample (A1493) is also shown, as is the shooting site (open circle) and direction (black arrow) of the photograph shown in Fig. 3. Light brown solid and dashed lines are elevation contours at 5 $\mathrm{m}$ and $2.5 \mathrm{~m}$ intervals, respectively. Modified from Turkki (2005). 
within rapakivi granite (Fig. 1; Suominen, 1991; Arponen, 2008; Arponen et al., 2009; Rämö \& Arponen, 2010).

\section{Analytical methods}

The dark wiborgite sample (A1493) was crushed and ground using a jaw crusher and a roller mill, respectively. After that, the heavy minerals were separated using heavy liquids (methylene diiodide and Clerici's solution) and Frantz magnetic separator. The final selection of the minerals for $\mathrm{U}-\mathrm{Pb}$ dating was done by hand picking. The decomposition of zircons and extraction of $\mathrm{U}$ and $\mathrm{Pb}$ for conventional isotopic age determination follows mainly the procedure described by Krogh $(1973,1982) .{ }^{235} \mathrm{U}$ ${ }^{208} \mathrm{~Pb}$-spiked and unspiked isotopic ratios were measured using a VG Sector 54 thermal ionization multicollector mass spectrometer. The measured lead and uranium isotopic ratios were normalized to the accepted ratios of SRM 981 and U500 standards. The $\mathrm{Pb} / \mathrm{U}$ ratios were calculated with PbDat program (vers.1.21; Ludwig, 1991). The concordia plot and the final age calculations were done using the Isoplot/Ex 3.00 program (Ludwig, 2003). The common lead corrections were done using the age related Stacey \& Kramers (1975) Pb isotope compositions $\left({ }^{206} \mathrm{~Pb} /{ }^{204} \mathrm{~Pb} \pm 0.2,{ }^{208} \mathrm{~Pb} /{ }^{204} \mathrm{~Pb}\right.$ \pm 0.2 , and $\left.{ }^{207} \mathrm{~Pb} /{ }^{204} \mathrm{~Pb} \pm 0.1\right)$. The total procedural $\mathrm{Pb}$ blank was $50 \mathrm{pg}$. All the ages are calculated with $2 \sigma$ errors and without decay constant errors.

A whole-rock powder was made from the ground fraction of the Ristisaari dark wiborgite (A1493) using a swing mill and a $-150 \mathrm{mg}$ of the powder was dissolved for two days in a teflon bomb at $180{ }^{\circ} \mathrm{C}$ in $\mathrm{HF}-\mathrm{HNO}_{3}$. Whole-rock powders from the Verla granite (sample A69; Vaasjoki et al., 1991) and the Ylijärvi granite (sample A791; Suominen, 1991) were dissolved the same way. The whole-rock powder from the Ylijärvi anorthosite (sample A119; Suominen, 1991) was dissolved in a Savillex screwcap teflon beaker. After evaporation the samples were dissolved in $\mathrm{HCl}$ to obtain a clear solution. The clear $\mathrm{HCl}$ solution was totally-spiked with a ${ }^{149} \mathrm{Sm}^{150} \mathrm{Nd}$ tracer and, for the anorthosite, also with a ${ }^{87} \mathrm{Rb}_{-}{ }^{84} \mathrm{Sr}$ tracer. $\mathrm{Rb}, \mathrm{Sr}$, and the light rare earth elements
(LREE) were separated using standard cation exhange chromatography, and Sm and $\mathrm{Nd}$ were purified using a modified version of the TeflonHDEHP method of Richard et al. (1976). The total procedural blanks were $<2 \mathrm{ng}$ for $\mathrm{Sr}$ and $<300 \mathrm{pg}$ for $\mathrm{Nd}$. Isotopic ratios of $\mathrm{Sr}, \mathrm{Sm}$, and $\mathrm{Nd}$ were measured on a VG SECTOR 54 mass spectrometer (those of $\mathrm{Nd}$ and $\mathrm{Sr}$ in dynamic mode). Isotope dilution for $\mathrm{Rb}$ was performed on a non-commercial Nier-type mass spectrometer built at the Geological Survey of Finland. Nd isotopic ratios were normalized to ${ }^{146} \mathrm{Nd} /{ }^{144} \mathrm{Nd}=0.7219$. Repeated analyses of the La Jolla $\mathrm{Nd}$ standard gave ${ }^{143} \mathrm{Nd}$ / ${ }^{144} \mathrm{Nd}$ of $0.511852 \pm 0.000013$ (mean and external $2 \sigma$ error of 63 measurements). The external $2 \sigma$ error on ${ }^{143} \mathrm{Nd} /{ }^{144} \mathrm{Nd}$ is $0.0025 \%$ and the $\mathrm{Sm}-\mathrm{Nd}$ ratios are estimated to be accurate within $0.5 \%$. The maximum error in the $\varepsilon_{\mathrm{Nd}}$ values is $\pm 0.4 \varepsilon$-units. $\mathrm{Sr}$ isotopic ratios were normalized to ${ }^{86} \mathrm{Sr} /{ }^{88} \mathrm{Sr}=0.1194$. Repeated analyses of the NBS $987 \mathrm{Sr}$ standard yielded ${ }^{87} \mathrm{Sr} /{ }^{86} \mathrm{Sr}$ of $0.710268 \pm 0.000042$ (mean and external $2 \sigma$ error of 23 measurements). The ${ }^{87} \mathrm{Sr} /$ ${ }^{86} \mathrm{Sr}$ are reported relative to ${ }^{87} \mathrm{Sr} /{ }^{86} \mathrm{Sr}=0.71024$. The external $2 \sigma$ error on ${ }^{87} \mathrm{Sr} /{ }^{86} \mathrm{Sr}$ is better than 0.006 $\%$ and the error in $\mathrm{Rb} / \mathrm{Sr}$ is $0.5 \%$.

In situ $\mathrm{Sr}$ isotope analyses of plagioclase were made across a single polished, homogeneous crystal of spectrolite plagioclase (sample YLI-1), recovered from an olivine leucogabbronorite in the southwestern margin of the Ylijärvi anorthosite body and mounted on a circular 2.5 -cm-diameter mount. The analyses were performed by laser ablation MC-ICPMS using a Nu Plasma HR multi-collector inductively coupled plasma mass spectrometry (MC-ICP-MS) and a Photon Machine Analyte G2 laser microprobe at the National SGL Laboratory at the Geological Survey of Finland. Samples were ablated in He gas (gas flows $=0.4$ and $0.1 \mathrm{l} / \mathrm{min}$ ) within a HelEx ablation cell (Müller et al., 2009). All analyses were made in static ablation mode using a beam diameter of 100 to $150 \mu \mathrm{m}$ (spot mode mostly), pulse frequency of $10 \mathrm{~Hz}$, and beam energy density of $2.07 \mathrm{~J} / \mathrm{cm}^{2}$. The MC-ICP-MS was equipped with nine Faraday detectors and amplifiers with $1011 \Omega$ resistors. During the laser ablation the data were collected in static mode ${ }^{84} \mathrm{Sr}-\mathrm{Kr},{ }^{85} \mathrm{Rb},{ }^{86} \mathrm{Sr}-\mathrm{Kr},{ }^{87} \mathrm{Rb}-$ 
$\mathrm{Sr},{ }^{88} \mathrm{Sr}$ ). Measured isotope ratios were corrected for instrument fractionation using an exponential law and a ${ }^{86} \mathrm{Sr} /{ }^{88} \mathrm{Sr}$ value of 0.1194 . The isobaric interference of ${ }^{87} \mathrm{Rb}$ on ${ }^{87} \mathrm{Sr}$ was monitored and corrected using the ${ }^{85} \mathrm{Rb}$ ion signal and a value of 0.38571 for the ${ }^{87} \mathrm{Rb} /{ }^{85} \mathrm{Rb}$ ratio. The isobaric interference of ${ }^{86} \mathrm{Kr}$ on ${ }^{86} \mathrm{Sr}$ was corrected using a $30 \mathrm{~s}$ background measurement, preceding every ablation. The ${ }^{87} \mathrm{Rb} /{ }^{86} \mathrm{Sr}$ ratio was used for age correction. The average total Sr signal obtained for plagioclase samples was $1 \mathrm{~V}$. Under these conditions, $120 \mathrm{~s}$ of ablation was needed to obtain an internal precision of $\leq \pm 0.00005(1 \sigma)$. A value for the decay constant of ${ }^{87} \mathrm{Rb}$ of $1.393 \times 10^{11} \mathrm{y}^{1}$ has been used in all calculations (Nebel et al., 2011). The accuracy of the laser ablation protocol was verified throughout the day of measurement by repeated analysis of an in-house plagioclase standard from a megacryst of the Cameroon volcanic chain (sample Mir a, Rankenburg et al., 2004). The laser ablation parameters were similar on the samples and the standards. During the course of this study, the average ${ }^{87} \mathrm{Sr} /$ ${ }^{86} \mathrm{Sr}$ value obtained was $0.70309 \pm 0.00006(2 \sigma$, $\mathrm{n}=5)$, similar to the TIMS value of $0.70311 \pm 0.0001$

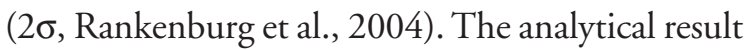
of the in-house standard range from 0.70305 to 0.70313 , which is similar to the reference value.

\section{Results}

\subsection{U-Pb zircon geochronology}

Zircon extracted from the ground fractions of the Ristisaari Island dark wiborgite sample was plenty. The largest $(>75 \mu \mathrm{m})$ crystals in the density fraction $>4.5 \mathrm{~g} / \mathrm{cm}^{3}$ were brownish (transparent or translucent) and prismatic and contained frequent dark inclusions. The finer-grained fraction primarily comprised colorless and clear fractions of larger crystals. Intact crystals were prismatic with varying length-width ratios. Two multigrain samples (0.59 $\mathrm{mg}$ and $0.48 \mathrm{mg}$ ) of abraded (cf. Krogh, 1982) crystals were analysed for $\mathrm{U}-\mathrm{Pb}$ isotopes from the $>4.5 \mathrm{~g} /$ $\mathrm{cm}^{3}$ fraction. The results are shown in Table 1 and they are plotted on a concordia diagram in Fig. 5.

The analyzed zircons are relatively low in $\mathrm{U}$

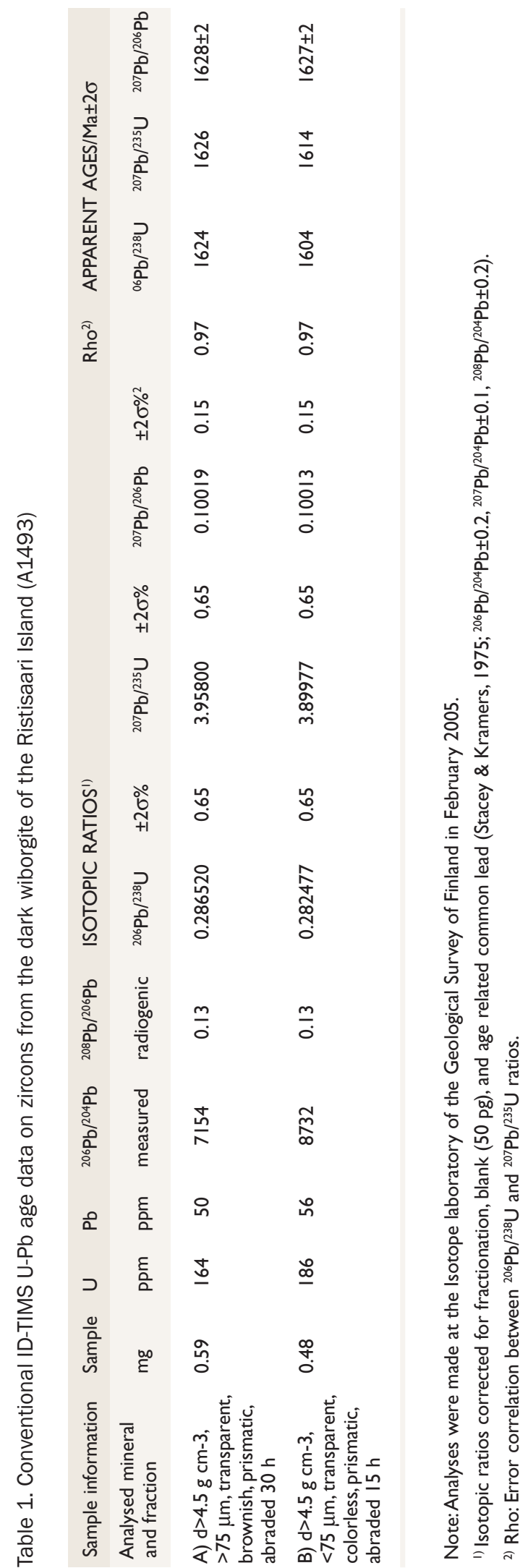




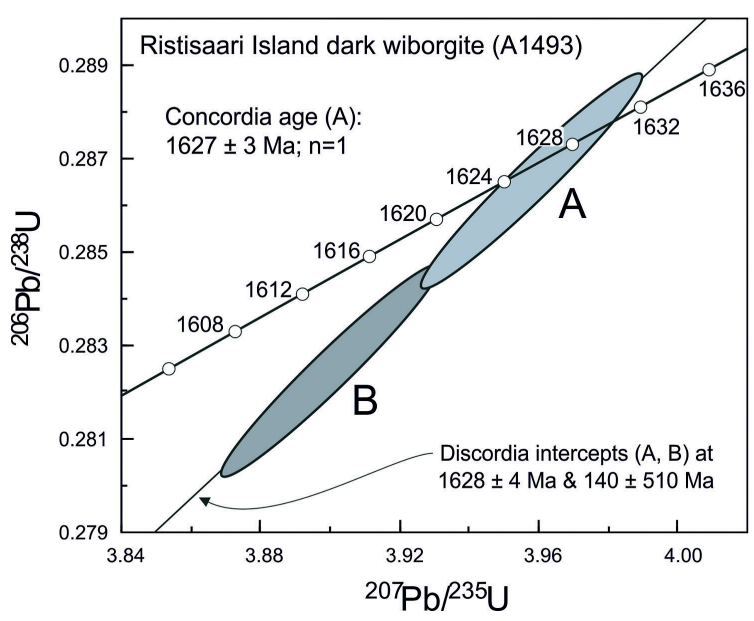

Fig. 5. U-Pb concordia diagram showing the results (Table 1) on the two multi-grain zircon fractions (A, B) analyzed from the dark wiborgite of the Ristisaari Island. Data-point error ellipses are at the $2 \sigma$ level.

$(\sim 160-190 \mathrm{ppm})$ and the ${ }^{206} \mathrm{~Pb} /{ }^{204} \mathrm{~Pb}$ and ${ }^{208} \mathrm{~Pb} /{ }^{206} \mathrm{~Pb}$ ratios of the two measured fractions are similar (Table 1). Fraction A (abraded for 30 hours) is concordant with a concordia age of $1627 \pm 3 \mathrm{Ma}$, fraction B (abraded for 15 hours) is slightly discordant with a ${ }^{207} \mathrm{~Pb} /{ }^{206} \mathrm{~Pb}$ age of $1627 \pm 2 \mathrm{Ma}$. The discordia intercepts are at $1628 \pm 4 \mathrm{Ma}$ and $140 \pm 510 \mathrm{Ma}$ and the upper intercept age is determined by the concordant point. The concordia age of fraction A sets the crystallization age of the Ristisaari dark wiborgite at $1627 \pm 3 \mathrm{Ma}$.
$111.9 \mathrm{ppm}$, respectively) and is slightly more enriched in the LREE $\left({ }^{147} \mathrm{Sm} /{ }^{144} \mathrm{Nd}=0.1048\right)$. The measured ${ }^{143} \mathrm{Nd} /{ }^{144} \mathrm{Nd}$ is $0.511604 \pm 0.000006$ $\left(2 \sigma_{\mathrm{m}}\right)$, initial (at $\left.1639 \mathrm{Ma}\right){ }^{143} \mathrm{Nd} /{ }^{144} \mathrm{Nd}$ is 0.510475 , initial $\varepsilon_{\mathrm{Nd}}$ value is -0.9, and depleted mantle model age is $2006 \mathrm{Ma}$.

The dark rapakivi granite from the vicinity of the Ylijärvi anorthositic body in the east-central part of the Wiborg batholith (Fig. 1) has much lower concentrations of Sm (9.47 ppm) and $\mathrm{Nd}$ (51.25 ppm), but is slightly more enriched in the LREE $\left({ }^{147} \mathrm{Sm} /{ }^{144} \mathrm{Nd}=0.1117\right)$ than the Ristisaari dark wiborgite. The measured ${ }^{143} \mathrm{Nd} /{ }^{144} \mathrm{Nd}$ is 0.511627 $\pm 0.000007\left(2 \sigma_{\mathrm{m}}\right)$, initial (at $\left.1633 \mathrm{Ma}\right){ }^{143} \mathrm{Nd} /{ }^{144} \mathrm{Nd}$ is 0.510428 , initial $\varepsilon_{\mathrm{Nd}}$ value -1.9 , and depleted mantle model age $2110 \mathrm{Ma}$. The spectrolite olivine leucogabbronorite from Ylijärvi has low values of Sm $(3.30 \mathrm{pm})$ and $\mathrm{Nd}(16.41 \mathrm{ppm})$ and it is slightly less enriched in the LREE $\left({ }^{147} \mathrm{Sm} /{ }^{144} \mathrm{Nd}=0.1217\right)$ than the granites analyzed in this study. The measured ${ }^{143} \mathrm{Nd} /{ }^{144} \mathrm{Nd}$ is $0.511745 \pm 0.000009\left(2 \sigma_{\mathrm{m}}\right)$, initial (at $1633 \mathrm{Ma}$ ) ${ }^{143} \mathrm{Nd} /{ }^{144} \mathrm{Nd}$ is 0.5104238 , initial $\varepsilon_{\mathrm{Nd}}$ value -1.7 , and depleted mantle model age 2143 Ma.

The $\mathrm{Nd}$ isotope composition of the four samples is shown in a ${ }^{147} \mathrm{Sm} /{ }^{144} \mathrm{Nd}$ vs. initial $\varepsilon_{\mathrm{Nd}}$ plot in Fig. 6. In terms of initial $\mathrm{Nd}$ isotope composition, the samples are almost identical within the experimental error of $\pm 0.4 \varepsilon$-units; a measurable (small) difference

\subsection{Sm-Nd isotope geochemistry}

The whole-rock Sm-Nd isotope composition of the Ristisaari dark wiborgite (Table 2) implies high values of $S \mathrm{~m}$ (19.95 ppm) and $\mathrm{Nd}(105.8 \mathrm{ppm})$ and strong enrichment in the LREE with a ${ }^{147} \mathrm{Sm} /{ }^{144} \mathrm{Nd}$ of 0.1139 . The measured ${ }^{143} \mathrm{Nd} /{ }^{144} \mathrm{Nd}$ is relatively high, $0.511686 \pm 0.000010\left(2 \sigma_{\mathrm{m}}\right)$. At 1627 $\mathrm{Ma}$, the initial ${ }^{143} \mathrm{Nd} /{ }^{144} \mathrm{Nd}$ is 0.510468 and the corresponding initial $\varepsilon_{\mathrm{Nd}}$ value is -1.3. The depleted mantle model age (DePaolo, 1981 ) is $2066 \mathrm{Ma}$. The Verla granite on the northwestern flank of the batholith also has high values of Sm and $\mathrm{Nd}$ (19.40 ppm and

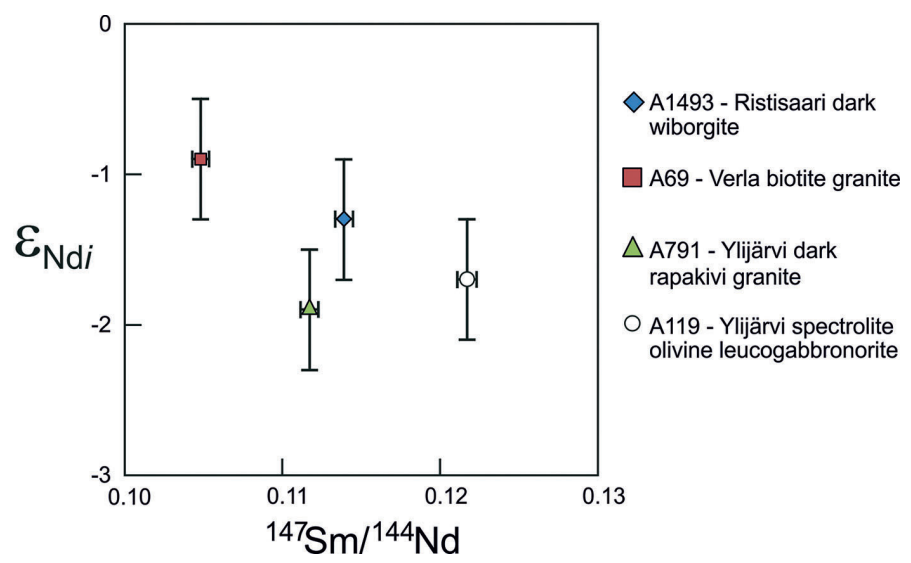

Fig. 6. Results of ID-TIMS whole-rock Sm-Nd isotope analysis (Table 2) of four rapakivi-related plutonic rocks from the Wiborg batholith shown in a ${ }^{147} \mathrm{Sm} /{ }^{144} \mathrm{Nd}$ vs. initial $\varepsilon_{\mathrm{Nd}}$ diagram. Error bars show the external errors $(2 \sigma)$ of the variables. 


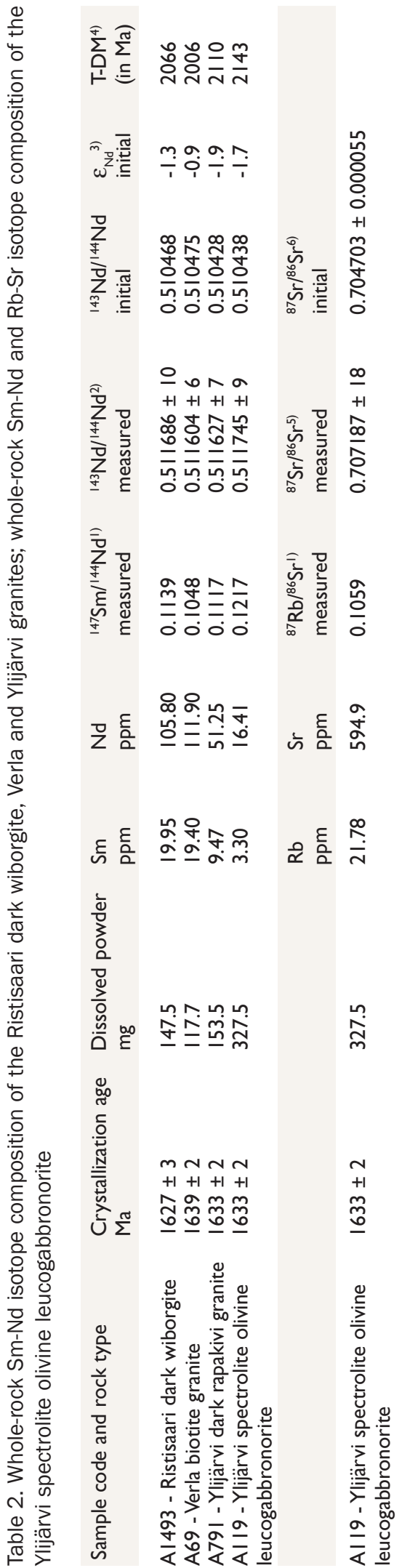

is evident between the Verla biotite granite $\left(\varepsilon_{\mathrm{Nd} i}-0.9\right)$ and the Ylijärvi dark rapakivi granite $\left(\varepsilon_{\mathrm{Nd} i}-1.9\right)$. The initial composition of the spectrolite olivine leucogabbronorite $\left(\varepsilon_{\mathrm{Nd} i}-1.7\right)$ is indistinguishable from that of the examined granites. The ${ }^{147} \mathrm{Sm} /{ }^{144} \mathrm{Nd}$ values of the analysed four samples are distinct. The spectrolite olivine leucogabbronorite has the highest $\mathrm{Sm} / \mathrm{Nd}$ and the Verla biotite granite the lowest, the Ristisaari dark wiborgite is intermediate between the dark rapakivi granite and spectrolite olivine leucogabbronorite (Fig. 6). These differences reflect, for the magmas from which these rocks crystallized, varying degrees of enrichment in the LREE.

\section{3. $R b$-Sr isotope geochemistry}

Of the samples of this study, only the purportedly low-Rb/Sr anorthosite was analyzed for whole-rock $\mathrm{Rb}-\mathrm{Sr}$ isotope composition. This was because high- $\mathrm{Rb} / \mathrm{Sr}$ rocks, owing to subsolidus mobility of $\mathrm{Rb}$ (and sometimes also Sr), often fail to register accurate magmatic values for Precambrian lithologic units (cf. Welin et al., 1983; Rämö, 1999; Rämö et al., 1996). The Rb-Sr isotope analysis of the Ylijärvi spectrolite olivine leucogabbronorite (Table 2) implies low $\mathrm{Rb}$ (21.78 ppm), high $\mathrm{Sr}(594.9 \mathrm{ppm})$ and thus low ${ }^{87} \mathrm{Rb} /{ }^{86} \mathrm{Sr}(0.1059)$. The measured ${ }^{87} \mathrm{Sr} /$ ${ }^{86} \mathrm{Sr}$ is $0.707187 \pm 0.000018\left(2 \sigma_{\mathrm{m}}\right)$ and the initial (at $1633 \mathrm{Ma}$ ) ${ }^{87} \mathrm{Sr} /{ }^{86} \mathrm{Sr}$ is $0.70470 \pm$ 0.00005 (Fig. 7).

The in situ laser ablation MC-ICP-MS data (12 spots from a single spectrolitic plagioclase megacryst from the Ylijärvi anorthositic body) are shown in Table 3 and in Fig. 7. The measured ${ }^{87} \mathrm{Rb} /{ }^{86} \mathrm{Sr}$ of the individual spots are very low (as expected for calcic plagioclase matrix) and the measured ${ }^{87} \mathrm{Sr} /{ }^{86} \mathrm{Sr}$ cluster relatively tightly between 0.70425 and 0.70536 . The calculated initial (at $1633 \mathrm{Ma}){ }^{87} \mathrm{Sr} /{ }^{86} \mathrm{Sr}$ values vary from 0.70391 to 0.70494 and average at 0.70424 


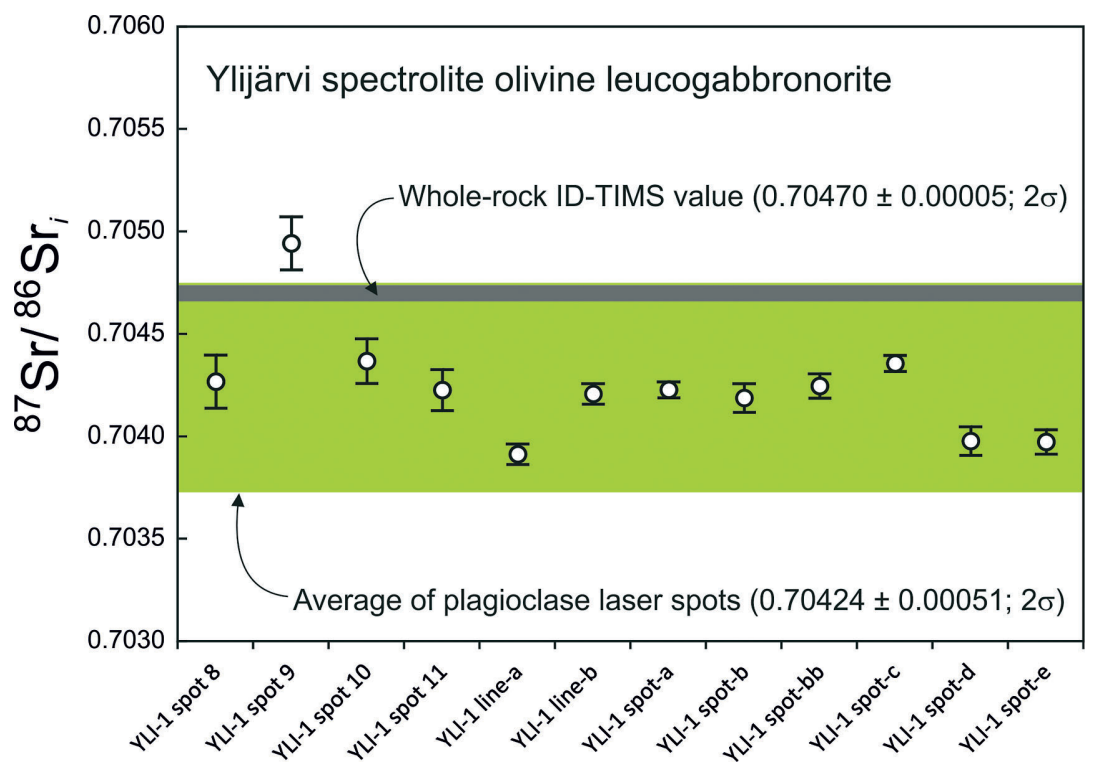

Fig. 7. Results of ID-TIMS wholerock (Table 2) and laser ablation MC-ICP-MS (Table 3) Rb-Sr isotope analyses of the Ylijärvi spectrolite olivine leucogabbronorite from the east-central part of the Wiborg batholith (Fig. 1). Horizontal axis is a break-down of the measured laser spots (Table 3). Error bars show the external errors $(2 \sigma)$ on the individual laser spots measured.

Table 3. Laser ablation MC-ICP-MS Rb-Sr isotope composition of spectrolite feldspar (sample YLI-1) from theYlijärvi anorthositic body

$\begin{array}{lccccccc}\text { Spot number } & \begin{array}{c}\text { Spot diameter } \\ \mu \mathrm{m}\end{array} & \text { Ablation mode } & \begin{array}{c}{ }^{87} \mathrm{Rb} /{ }^{86} \mathrm{Sr} \\ \text { measured }\end{array} & \begin{array}{c}{ }^{87} \mathrm{Sr}^{866} \mathrm{Sr}^{1)} \\ \text { measured }\end{array} & 2 \sigma & \begin{array}{c}{ }^{87} \mathrm{Sr}^{86} \mathrm{Sr}^{2)} \\ \text { initial }\end{array} & 2 \sigma \\ \text { YLI-I spot } 8 & 100 & \text { Spot } & 0.0179 & 0.70468 & 0.00010 & 0.70427 & 0.00013 \\ \text { YLI-I spot } 9 & 100 & \text { Spot } & 0.0180 & 0.70536 & 0.00011 & 0.70494 & 0.00013 \\ \text { YLI-I spot 10 } & 100 & \text { Spot } & 0.0239 & 0.70492 & 0.00008 & 0.70437 & 0.00011 \\ \text { YLI-I spot II } & 100 & \text { Spot } & 0.0095 & 0.70444 & 0.00009 & 0.70422 & 0.00010 \\ \text { YLI-I line-a } & 110 & \text { Line } & 0.0148 & 0.70425 & 0.00004 & 0.70391 & 0.00005 \\ \text { YLI-I line-b } & 110 & \text { Line } & 0.0161 & 0.70458 & 0.00004 & 0.70421 & 0.00005 \\ \text { YLI-I spot-a } & 150 & \text { Spot } & 0.0203 & 0.70469 & 0.00003 & 0.70423 & 0.00004 \\ \text { YLI-I spot-b } & 150 & \text { Spot } & 0.0237 & 0.70473 & 0.00003 & 0.70419 & 0.00007 \\ \text { YLI-I spot-bb } & 150 & \text { Spot } & 0.0131 & 0.70455 & 0.00004 & 0.70424 & 0.00006 \\ \text { YLI-I spot-c } & 150 & \text { Spot } & 0.0157 & 0.70472 & 0.00003 & 0.70435 & 0.00004 \\ \text { YLI-I spot-d } & 150 & \text { Spot } & 0.0265 & 0.70459 & 0.00004 & 0.70398 & 0.00007 \\ \text { YLI-I spot-e } & 150 & \text { Spot } & 0.0207 & 0.70445 & 0.00004 & 0.70397 & 0.00006\end{array}$

Note:Analyses were made at the National SGL Laboratory (Suomen geologian tutkimuslaboratorio),

Geological Survey of Finland

I) Monitored against an in-house plagioclase standard from a megacryst of the Cameroon volcanic chain (sample Mir a; Rankenburg et al., 2004). The average ${ }^{87} \mathrm{Sr} /{ }^{86} \mathrm{Sr}$ value obtained for Mir a during the measurement of the YLI-I sample was $0.70309 \pm 0.00006(2 \sigma, n=5)$, similar to the TIMS value of $0.703 \mathrm{II} \pm 0.000 \mathrm{I}(2 \sigma)$ of Rankenburg et al. (2004)

2) Calculated using the ID-TIMS age of $1633 \pm 2$ Ma (see Appendix).

$\pm 0.00051(2 \sigma)$. At face value, this is somewhat lower than the ID-TIMS bulk whole-rock initial value, and some of the discordancy observed may stem from the fact that the one plagioclase crystal analyzed may not completely reflect the isotope composition of the rock forming minerals in the olivine leuco- gabbronorite. However, within the experimental error, the values are compatible (Fig. 7) and the isotope composition of $\mathrm{Sr}$ of this spectrolitic massiftype anorthosite is thus confirmed by two individual methods. The compositional variation observed across the examined homogeneous spectrolite crystal 
may reflect slight subsolidus redistribution of $\mathrm{Rb}$ and $\mathrm{Sr}$, with radioactive decay of ${ }^{87} \mathrm{Rb}$ to ${ }^{87} \mathrm{Sr}$ since $-1630 \mathrm{Ma}$ having resulted in domains with slight differences in ${ }^{87} \mathrm{Sr} /{ }^{86} \mathrm{Sr}$.

\section{Discussion}

\subsection{Lithology of the Wiborg batholith and significance of the dark wiborgite}

The lithologic map of the Finnish part of the Wiborg batholith (Fig. 1) implies, for the present erosional level, a versatile series of granite types that vary in composition and relative abundance. The current perception of this variation is based on bedrock mapping performed in southeastern Finland in the 1950s and 1960s by the Geological Survey of Finland, the results of which were summarized by Vorma (1971) and Simonen (1987). Vorma (1971) divided the granitic sequence of the Wiborg batholith into eight lithologic groups:

\section{Dark equigranular granites}

Relatively plagioclase-rich, green, dark gray, and black granites with accessory fayalite; e.g., the tirilites around Lappeenranta and equigranular granites in the coastal islands in the southern part of the batholith, the latter with dark plagioclase megacrysts.

\section{Equigranular hornblende granites}

Relatively mafic, fayalite-bearing hornblende granites; e.g., the dark red Lappee granite (Hackman, 1934) on the northeastern flank of the batholith and granites on the southern rim of the Suomenniemi complex and in the Jaala-Iitti complex (Fig. 1).

\section{Wiborgites}

The typical rapakivi granites with alkali feldspar ovoids mantled by plagioclase and hornblende as the main mafic silicate; includes both the wiborgite and the dark wiborgite. Wiborgites represent the main build-up stage of the batholith.

\section{Pyterlites}

Relatively large bodies (maximum dimension of $\sim 10$ $\mathrm{km}$ ) of reddish rapakivi granite characterized by unmantled alkali feldspar ovoids and biotite as the main mafic silicate; most of these bodies are found in the west-central and northern parts of the batholith (Fig. 1). The pyterlites are often, but not always, gradational to wiborgites.

\section{Porphyritic granites}

Granites with angular, not ovoid, and unmantled alkali feldspar megacrysts, often seriate; red to light gray in color (e.g., the Sinkko granite in the Lappeenranta area). The most substantial bodies of porphyritic rapakivi granite are found in the northern part of the batholith (Fig. 1).

\section{Equigranular biotite granites}

Versatile bodies of usually red or reddish, equigranular biotite granites; some topaz-bearing such as the marginal facies of the Kymi granite cupola (Fig. 1; Haapala, 1974). Coeval or younger than wiborgite.

\section{Porphyry aplites}

Small biotite rapakivi granite bodies characterized by sparse and scattered alkali feldspar ovoids, mantled or unmantled by plagioclase, in fine-grained aplite-granitic groundmass. Often gradational to biotite granite.

\section{Dike rocks}

Granite porphyry, quartz porphyry, porphyry aplite, and aplite dikes that cut the plutonic rock types of the batholith.

Overall, these silicic rocks show a substantial variation in petrographic, mineralogical, and geochemical terms, from low-SiO, high-CaO melanocratic fayalite-bearing hornblende granites (tirilite, dark wiborgite, equigranular hornblende granite) to high-SiO${ }_{2}$, low-CaO leucocratic topaz-bearing leucogranites (e.g., Vorma, 1976; Haapala, 1977; 
Rämö \& Haapala, 2005). The most melanocratic rock types, the dark equigranular granites (Vorma's group I) in the southern, off-shore part of the batholith and the dark wiborgites (Vorma's group III) in the western and southern parts of the batholith are characterized by dark plagioclase megacrysts. The significance of these dark megacrysts has not been paid much attention to - their presence in these rocks has been noted (e.g., Wahl, 1925; Vorma, 1971; Simonen, 1987) but not elaborated.

Turkki (2005) determined the composition (molar proportion of the An component) of plagioclase from the dark wiborgite (Fig. 2b) and associated rapakivi granites of the Ristisaari Island utilizing optical crystallography. Even though less meticulous and less accurate than state-of-the-art geochemical methods (e.g., EPMA), the resolution is considered ample for the purpose. The optical Michel-Lévy method for measuring the maximum symmetrical extinction of albite twins in sections normal to 010 was used, applying the universal stage (Dodge, 1934) for adjusting the orientation of the examined grains and the curves from Tröger et al. (1979) for lowtemperature plagioclase to read the respective compositions from. The results (cf. Table 5 in Turkki, 2005) of eight measurements of dark plagioclase megacrysts from the dark wiborgites and fayalitebearing melagranites, 15 plagioclase rims around alkali feldspar ovoids from the dark wiborgites, a melagranite dike, and densely-packed wiborgite, and 24 plagioclase phenocrysts from dark wiborgites, melagranite dikes, and densely-packed wiborgite are shown in Fig. 8. The dark plagioclase megacrysts are more calcic than the plagioclase that forms the rims of the alkali feldspar ovoids, with compositional ranges of $\mathrm{An}_{39-52}$ and $\mathrm{An}_{26-39}$, respectively. The composition of the plagioclase phenocrysts $\left(\mathrm{An}_{24-43}\right)$ and dark plagioclase megacrysts have some overlap, but, on average, the megacrysts are more calcic (Fig. 8).

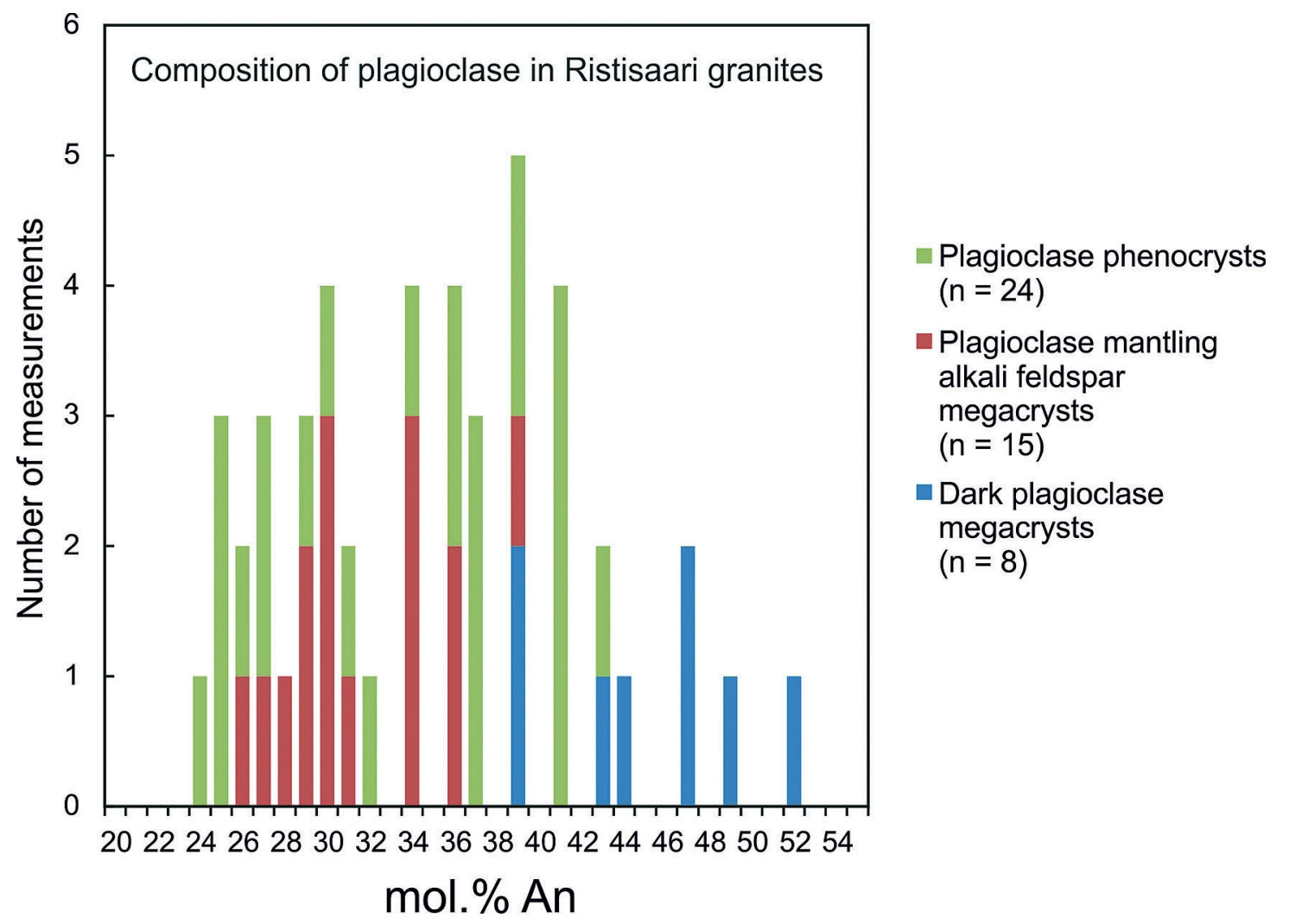

Fig. 8. Histogram showing the composition (mol.\% An) of plagioclase from the dark wiborgites, fayalite-bearing melagranites, and densely packed wiborgite from the Ristisaari Island. See text for further details. 
The composition of the dark plagioclase megacrysts $\left(\mathrm{An}_{39-52}\right)$ is more calcic than plagioclasemelt equilibrium compositions in granitic systems (cf. Scaillet et al., 1995). Evidently, these megacrysts are xenocrystic in origin. They probably represent andesine-labradorite crystals that originally grew in mafic magmas parental to the massif-type anorthosites associated with the Wiborg batholith. Such mafic magma systems developed profusively in the lower crust-mantle interface during the emplacement of the Wiborg batholith (e.g., Rämö \& Haapala, 2005; Heinonen et al., 2010a). These mafic magmas presumably interacted with alkali feldspar-megacrystic rapakivi granite magmas to produce the dark wiborgites, which may thus be considered mixed granitic rocks with calcic plagioclase xenocrysts (see also Turkki, 2005).

\subsection{Intrusion sequence of the Wiborg batholith}

The emplacement of the locus classicus Finnish and Russian Karelian rapakivi granites occurred in midProterozoic times and, on a global scale, they belong to the so-called mid-Proterozoic anorogenic granites (cf. Anderson, 1983). Two distinct events have been recognized: the Wiborg batholith and its satellitic intrusions are older $(-1650-1620 \mathrm{Ma})$ than the Aland batholith and associated plutons in southwestern Finland $(-1590-1540 \mathrm{Ma})$ and the Salmi batholith in Russian Karelia (1560-1540 Ma) (Vaasjoki, 1977; Suominen, 1991; Vaasjoki et al., 1991; Neymark et al., 1994). The tectonic regime of the rapakivi granites was extensional, as exemplified by the coeval diabase dike swarms associated with the intrusions in southeastern and southwestern Finland (e.g., Haapala \& Rämö, 1990).

The age relations of the various rock types of the Wiborg batholith have been examined since the early field studies in the $19^{\text {th }}$ century (Sederholm, 1891). Observations from outcrops led Vorma (1971) to conclude that (1) the tirilite is older than wiborgite; (2) the dark, equigranular granites in the coastal islands may be younger than wiborgite; (3) the Jaala-Iitti complex on the western flank of the batholith (Fig. 1) is younger than wiborgite; (4) pyterlite is (mostly) coeval with wiborgite; (5) the porthyritic granites are coeval with wiborgite and pyterlite; (6) the equigranular biotite granites are coeval with or younger than wiborgite; and (7) the porphyry aplites are coeval with biotite granites. Overall, Vorma (1971) proposed three to four major intrusive phases for the Wiborg batholith (see also Simonen, 1987):

$1^{\text {st }}$ intrusive phase: Tirilite-Lappee graniteSinkko granite

$2^{\text {nd }}$ intrusive phase: Dark wiborgite-wiborgitehornblende granite-pyterlite-porphyritic granitebiotite granite-porphyry aplite

$3^{\text {rd }}$ intrusive phase: The Jaala-Iitti dike (possibly also dark rapakivi granites in the Gulf of Finland area)

$4^{\text {th }}$ (possible) intrusive phase: Quartz porphyry dikes

The Wiborg batholith is a major epizonal granite complex with a diameter of $-150 \mathrm{~km}$ and probably constitutes an amalgamation of several different intrusive events that comprised a series of melts derived from deep sources and intruded into the upper crust in sequence. A Phanerozoic corollary of such systems are nested caldera complexes that were built up of dozen or more individual intrusive phases over a time interval of $\sim 10$ m.y. A good example is the large ( 35 by $80 \mathrm{~km})-24-13 \mathrm{Ma}$ Caliente caldera complex in southeastern Nevada (Rowley et al., 1992). The complex was formed during the main episode of extension in the eastern Basin and Range province and the locus of magmatism (governed by unexposed subsurface magma chambers) is delineated by 13 pyroclastic events scattered over extensive areas in southeastern Nevada and southwestern Utah. Overall, this extended terrain comprises three caldera complexes (Caliente, Indian Peak, Kane Springs Wash) that crop out over an area of 80 by $160 \mathrm{~km}$ (Fig. 1 in Rowley et al., 1992). The concealed magmatic system at subsurface levels may even have been larger in plan. The Wiborg batholith probably constitutes a deeper section of a consanguineous granite-rhyolite system emplaced at upper crustal levels during 
crustal extension in the mid-Proterozoic. Evidence for pyroclastic silicic rocks associated with the Wiborg batholith is sparse. Contemporaneous volcanic rocks (rhyolite lava and tuff, basalt) are, however, present in a down-faulted crustal block south of the batholith (Suursaari Island, Figs. 1, 3; Wahl, 1947; Levchenkov et al., 1998; Rämö et al., 2007) as well as in a megaxenolith in the northern part of the batholith (Harju et al., 2010).

The actual life span of the magmatic system of the Wiborg batholith is yet to be determined and will have to rely on high-precision $\mathrm{U}-\mathrm{Pb}$ mineral (zircon, baddeleyite) geochronology. The first U$\mathrm{Pb}$ ages on the Finnish rapakivi granites were published by Kouvo (1958) in a pioneering study of applying zircon geochronology to the Precambrian of Finland. Six samples (five from the Wiborg batholith and vicinity, one from the Kokemäki granite associated with the Laitila rapakivi granite batholith in southwestern Finland) indicated ${ }^{207} \mathrm{~Pb}-{ }^{206} \mathrm{~Pb}$ ages with face values in the $1675-1630$ Ma range and external errors of 2-4\% ( \pm 30 to 70 m.y. at $1650 \mathrm{Ma}$ ). A subsequent, comprehensive study of the zircon geochronology of the Wiborg batholith was published by Vaasjoki (1977), who concluded that the emplacement of the batholith occurred over a time interval of $\sim 50$ m.y. at $\sim 1700$ $1650 \mathrm{Ma}$. The results were based on U-Pb analyses of large single zircon fractions and the Wasserburg diffusion model (Wasserburg, 1963) and were reported with quantitative error estimates, typically on the order of 0.5 to $\geq 1 \%$ at the $95 \%$ confidence level. These early results were refined by Vaasjoki et al. (1991) and Suominen (1991) who utilized multiple zircon fractions separated from the samples examined and the air abrasion technique (Krogh, 1982); this allowed an improved accuracy of $\sim 0.3$ to $0.6 \%$. These data led Vaasjoki et al. (1991) to conclude that the Wiborg batholith was emplaced mainly between 1650 and $1625 \mathrm{Ma}$. The U-Pb zircon results of Vaasjoki et al. (1991) and Suominen (1991) were summarized by Vaasjoki (1996). The results comprise, for the silicic rocks of the Wiborg batholith, upper intercept and concordia ages for 18 plutonic rocks and eight subvolcanic rocks. These are shown, together with our new U-
$\mathrm{Pb}$ data on the dark wiborgite of the Ristisaari Island and recent data on the Leviänlahdenvuoret quartzfeldspar porphyry of the Ahvenisto complex (Heinonen et al., 2010a), in Fig. 9.

In view of the $-10-20$ m.y. life-span of major Phanerozoic silicic complexes involving evolution and emplacement of consecutive magmatic systems at $\sim 1$ m.y. pace (e.g., Rowley et al., 1992; Gehrels et al., 2009; Walker \& Grunder, 2010), a better precision yet is needed to unravel the quantitative temporal evolution and absolute age differences of the various rock types and purported intrusive phases (see above) of the Wiborg batholith. Most of the ages currently available for the Wiborg batholith do not meet this level of accuracy (Fig. 9). Granite samples with $\mathrm{U}-\mathrm{Pb}$ zircon upper intercept/concordia ages associated with external errors below $2.5 \%$ ( \pm $4 \mathrm{Ma}$ or better at $-1650 \mathrm{Ma}$ ) are highlighted in Fig. 9 (red circles and blue diamond) and the location of these samples is shown in Fig. 1. The oldest is the $1646 \pm 4$ Ma Värtö tirilite (sample A18) on the northern flank of the batholith and the youngest is our $1627 \pm 3$ Ma Ristisaari dark wiborgite (sample A1493) in the southern part of the batholith. These values imply a minimum time window of 12 m.y. for the emplaced of the plutonic rocks of the Wiborg batholith. In the northern part of the batholith, the Verla porphyritic biotite granite (sample A69), the Pohjalampi hornblende granite (sample A1043) of the Suomenniemi complex and three basic/ intermediate plutonic rocks (leucogabbronorite, anorthosite, quartz monzodiorite) from the Ahvenisto complex (Heinonen et al., 2010a; Fig. 1) are coeval at $\sim 1640 \mathrm{Ma}$. The $1633 \pm 2 \mathrm{Ma}$ Ylijärvi dark rapakivi granite (sample A791) and the $1632 \pm 2 \mathrm{Ma}$ Muurikkala wiborgite (sample A29) in the central part of the batholith (Fig. 1) are measurably younger than the granites in the north and, together with the Ristisaari Island dark wiborgite, show that the overall locus of magmatic activity may have shifted southward during the build-up of the Wiborg batholith. However, the major pyterlite body on the northern edge of the batholith (the $1631 \pm 4 \mathrm{Ma}$ Parola pyterlite, sample A629; Fig. 1) is younger than the Pohjalampi hornblende granite and the Verla biotite granite and shows that plutonic activity 


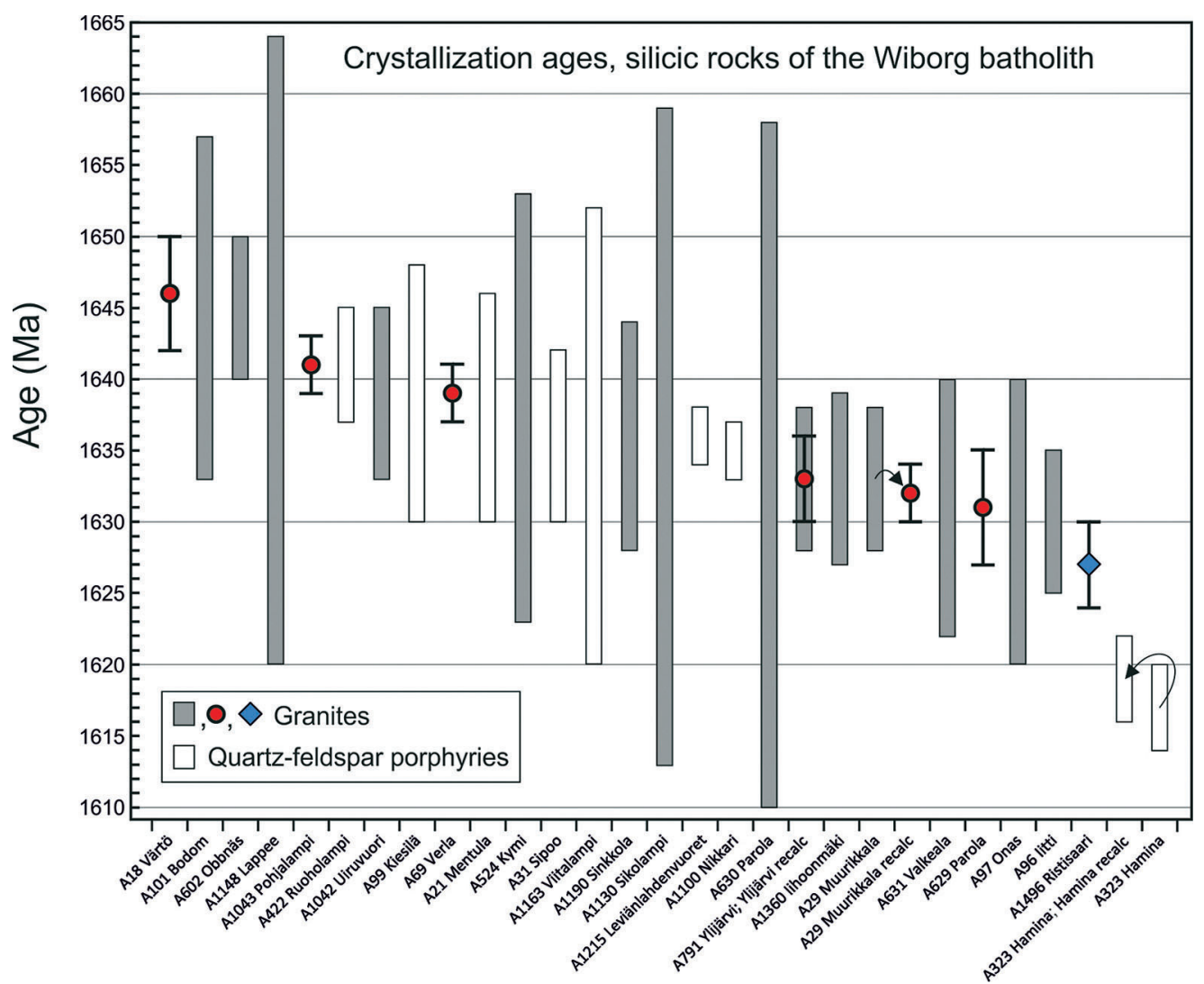

Fig. 9. U-Pb zircon multi grain ages (upper intercept or concordia) of silicic rocks (19 granites, eight subvolcanic dikes) from the Wiborg batholith. Error bars imply the external $(2 \sigma)$ error of the individual determinations, keyed to the respective samples by the horizontal axis. Plutonic samples marked with red dots and blue diamond are those with external errors better than 2.5\%. The data set includes three samples (A29 Muurikkala, A791 Ylijärvi, A323 Hamina) for which recalculated age values (see Appendix) are shown. Data from the compilation by Vaasjoki (1996) and this study.

on the northern flank of the batholith was resumed after the $-1640 \mathrm{Ma}$ event.

For a comprehensive picture of the emplacement history of the Wiborg batholith, more accurate ages are obviously needed, from the western part of the batholith in particular (Fig. 1). A crucial issue will be to verify the possible existence of discrete magmatic centers across the batholith and how they may relate to the distribution of the main granite types (dark wiborgite, wiborgite, and pyterlite in particular). The quartz-feldspar porphyry dikes that cut the plutonic rocks of the Wiborg batholith area include three with $\mathrm{U}-\mathrm{Pb}$ ages with errors better than $2.5 \%$ (Fig. 9). These come from the Ahvenisto (the 1636 $\pm 2 \mathrm{Ma}$ Leviänlahdenvuoret dike, sample A1215) and Suomenniemi (the $1635 \pm 2$ Ma Nik- kari dike, sample A1100) complexes as well as from the central part of the main batholith (the $1619 \pm 3$ Ma Hamina dike, sample A323). They show that rapakivi granite magmas were emplaced at much shallower levels after the crystallization of the plutonic rocks, with minimum amagmatic windows of -2 m.y. in the north (the $-1640 \mathrm{Ma}$ basic and intermediate rocks of the Ahvenisto complex vs. the $1636 \pm 2 \mathrm{Ma}$ Leviänlahdenvuoret dike; and the $1641 \pm 2 \mathrm{Ma}$ Pohjalampi granite vs. the $1635 \pm 2 \mathrm{Ma}$ Nikkari dike) and $-8 \mathrm{~m} . \mathrm{y}$. in the south (the $1632 \pm 2$ Ma Muurikkala wiborgite vs. the $1619 \pm 3 \mathrm{Ma} \mathrm{Ha}-$ mina dike). Combined, the silicic samples with crystallization ages with errors better than $2.5 \%$ (Fig. 9) imply a minimum age window of 20 m.y. for the emplacement of the Wiborg batholith. 


\subsection{Nd and Sr isotope constraints on the petrogenesis of the Wiborg batholith}

Radiogenic isotope compositions (e.g., $\mathrm{Nd}$ and $\mathrm{Sr}$ ) have been widely used to examine the sources and magmatic evolution of granites and associated rocks (e.g., Farmer and DePaolo, 1983; Huhma, 1986). They have also been extensively applied in the study of the Fennoscandian rapakivi granites and related mafic rocks (see Rämö, 1991, 1999, 2001; Neymark et al., 1994; Rämö et al., 1996; Heinonen et al., 2010a, b). The rapakivi granites of Finland show relatively radiogenic, slightly negative initial $\varepsilon_{\mathrm{Nd}}$ values that imply major source regions in the Svecofennian 1.9 Ga crust (e.g., Rämö, 1991). The Russian Karelian rapakivi granites are less radiogenic (more negative initial $\varepsilon_{\mathrm{Nd}}$ values; e.g., Neymark et al., 1994) and imply older overall sources with a mixed Paleoproterozoic lower crust as a major source component. The associated mafic rocks (gabbroic rocks, anorthosites, monzodiorites) have, in general, rather similar initial isotope compositions and hence ambiguity has prevailed as to whether the granites and the more mafic rocks were comagmatic or not. Recent Hf-in-zircon data (Heinonen et al., 2010b) have shed some new light on this source controversy, as they bear evidence for a mantle source for the mafic rocks of the association (that does not show in zircons from the analyzed rapakivi granites).

Our combined whole-rock Nd-Sr isotope data on the Ylijärvi spectrolite olivine leucogabbronorite are compared with data on troctolite, olivine leucogabbronorites, leucogabbronorites, and anorthosites from the Ahvenisto complex in the northern part of the Wiborg batholith (Heinonen et al., 2010a) and olivine gabbronorite and

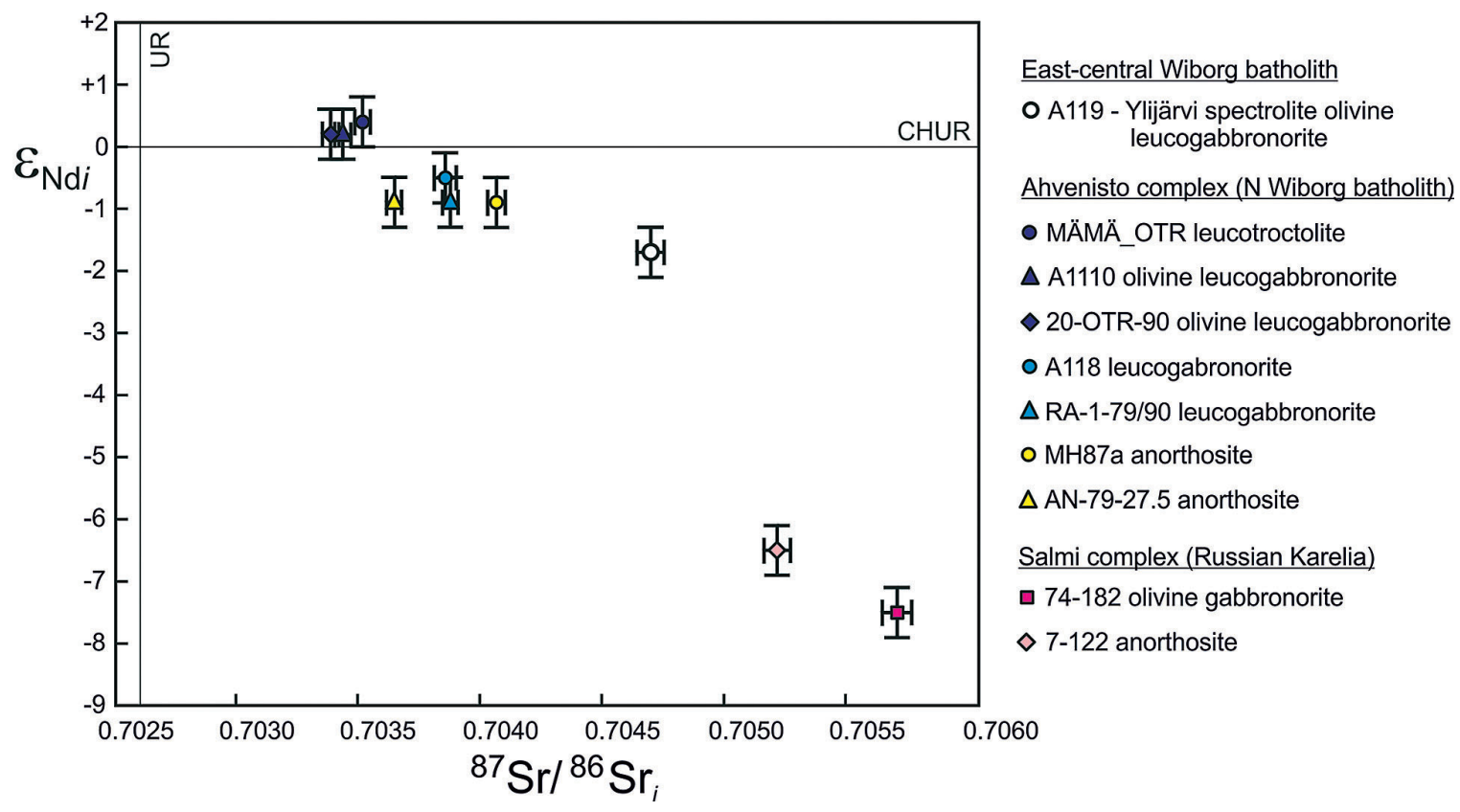

Fig. 10. Initial ${ }^{87} \mathrm{Sr} /{ }^{86} \mathrm{Sr}$ vs. initial $\varepsilon_{\mathrm{Nd}}$ diagram showing the whole-rock isotope composition of the Ylijärvi spectrolite olivine leucogabbronorite (Table 2) compared to the composition of various gabbroic and anorthositic rock units of the 1640 Ma Ahvenisto complex (northern flank of the Wiborg batholith; Fig. 1) and the 1560 Ma Salmi complex (exposed along the northern shore of Lake Ladoga in Russian Karelia). Reference data from Heinonen et al. (2010a) (Ahvenisto) and Neymark et al. (1994) (Salmi). CHUR is the time-integrated Nd isotope composition of the Chondritic Uniform Reservoir (DePaolo \& Wasserburg, 1981), UR is the Sr isotope composition of chondritic material at $1600 \mathrm{Ma}$, calculated from the ${ }^{87} \mathrm{Sr} /{ }^{86} \mathrm{Sr}=0.69899$ of Basaltic Achodrite Best Initial (BABI) using ${ }^{87} \mathrm{Rb} /{ }^{86} \mathrm{Sr}=0.0827$ (cf. Faure, 2001). Error bars show the external errors $(2 \sigma)$ of the variables. 
anorthosite from the Salmi complex in Russian Karelia (Neymark et al., 1994) in Fig. 10. The Ylijärvi olivine leucogabbronorite is measurably less juvenile (lower intial $\varepsilon_{\mathrm{Nd}}$, higher initial ${ }^{87} \mathrm{Sr} /{ }^{86} \mathrm{Sr}$ ) than the corresponding lithologic units from the Ahvenisto complex and more juvenile (higher initial $\varepsilon_{\mathrm{Nd}}$, lower initial ${ }^{87} \mathrm{Sr} /{ }^{86} \mathrm{Sr}$ ) than the samples from the Salmi complex. This shows that the isotope composition of $\mathrm{Nd}$ and $\mathrm{Sr}$ of the mafic magmas from which these rocks crystallized probably reflects overall compositional variation in the cratonic lithosphere (Paleoproterozoic for Ahvenisto, Paleoproterozoic-Archean for Salmi) where they were derived from/emplaced at. The Ylijärvi sample points to the possibility that there is subtle yet measurable variation in the time-integrated composition of the lithosphere across the Wiborg batholith area with a domain with older signature in the east-central part of the batholith (Fig. 1). This also shows in the composition of the analyzed granites, as the Verla biotite granite in the north has a more juvenile $\mathrm{Nd}$ isotope composition than the Ylijärvi dark rapakivi granite that is spatially associated with the Ylijärvi spectrolite olivine leucogabbronorite (Fig. 6).

\section{Concluding remarks}

The dark wiborgite of the Ristisaari Island is an important piercing point in terms of its age (the youngest plutonic rapakivi granite thus far recovered from the Wiborg batholith) and mineralogical traits (calcic plagioclase xenocrysts probably derived from consanquineous massif-type anorthosite magmas). The isotope composition of the Ylijärvi spectrolite olivine leucogabbronorite and the associated dark rapakivi granite may attest to a comparatively old lithospheric domain underneath the east-central part of the batholith and implies that isotopic homogenization did not occur on a batholith scale in the Wiborg magmatic system. In order to establish a time-integrated, source-associated emplacement model for the Wiborg batholith magmatic system, more high-accurracy U-Pb mineral data and $\mathrm{Nd}-\mathrm{Sr}$ isotope data are in order. An Academy of Finland project "Magma dynamics and crystallization of A- type granite magma chambers as revealed by in situ isotopic and elemental geochemical analysis of feldspar megacrysts" (2012-2016; O.T. Rämö, PI) has been recently launched to make a contribution to this end.

\section{Acknowledgments}

This work was funded by the Academy of Finland (grant 1259813 to OTR) and the Cultural Foundation of Finland (grant from the Uuno Klami Fund to OTR). Logistical help from the off-shore crew (Ari Laine and Jussi Sutela) of the Finnish Forest Administration (Metsähallitus) and Professor Pentti S. Pitkänen is highly appreciated. Professors Olav Eklund (Åbo) and Alvar Soesoo (Tallinn) and Dr. Jussi Heinonen (Editor-in-Chief of the Bulletin of the Geological Society of Finland) provided insightful reviews of the submitted manuscript, which is gratefully acknowledged. We also thank Arto Pulkkinen (Geological Survey of Finland) for skillfully running the Rbid fraction of the Ylijärvi spectrolite olivine leucogabbronorite whole rock.

\section{References}

Alviola, R., Johanson, B.S., Rämö, O.T. \& Vaasjoki, M. 1999. The Proterozoic Ahvenisto rapakivi granite - massif-type anorthosite complex, southeastern Finland; Petrography and U-Pb chronology. In: Haapala, I. \& Rämö, O.T. (Eds.), Rapakivi Granites and Related Rocks. Precambrian Research 95, 89-107.

Anderson, J.L. 1983. Proterozoic anorogenic granite plutonism of North America. In: Madaris, L.G. Jr., Byers, C.W., Mickelson, D.M. \& Shanks, W.C. (Eds.), Proterozoic geology. Geological Society of America Memoir 161, 133154.

Andersson, U.B. \& Eklund, O. 1994. Cellular plagioclase intergrowths as a result of crystal-magma mixing in the Proterozoic Åland rapakivi batholith, SW Finland. Contributions to Mineralogy and Petrology 117, 124136.

Arponen, E. 2008. Proterotsooiset massiivityypin anortosiitit ja erityisesti niissä tavattava spektroliitti Kakkois-Suomessa Ylämaalla. M.Sc. thesis, Department of Geology, University of Helsinki. [in Finnish]

Arponen, E., Härmä, P., Selonen, O., Luodes, H. \& Pokki, J. 2009. Anortosiitin ja spektroliitin esiintyminen Viipurin rapakivigraniittibatoliitissa ja spektroliittiesiintymien litologinen kontrolli. English summary: Anorthosite and spectrolite in the Wiborg rapakivi granite batholith and the lithological control of spectrolite deposits. Geological Survey of Finland, Report of Investigation 178, 41 p.

Ashwal, L.D. 1993. Anorthosites. Springer-Verlag, Berlin Heidelberg, 422 p. 
Bonin, B. 2007. A-type granites and related rocks; evolution of a concept, problems and prospects. In: Frost, C.D., Rämö, O.T. \& Dall'Agnol, R. (Eds.), IGCP-510: A-type Granites and Related Rocks through Time, Special Issue. Lithos 97, 1-29.

Cook, N.J., Sundblad, K., Valkama, M., Nygård, R., Ciobanu, C.L. \& Danyushevsky, L. 2011. Indium mineralization in A-type granites in southeastern Finland: Insights into mineralogy and partitioning between coexisting minerals. Chemical Geology 284, 62-73.

Dall'Agnol, R., Frost, C.D. \& Rämö, O.T. 2012. IGCP Project 510 "A-type Granites and Related Rocks through Time": Project vita, results, and contribution to granite research. Lithos 151, 1-16; doi: 10.1016/j.lithos.2012.08.003

DePaolo, D.J. 1981. Neodymium isotopes in the Colorado Front range and crust-mantle evolution in the Proterozoic. Nature 291, 193-196.

DePaolo, D.J. \& Wasserburg, G.J. 1976. Nd isotopic variations and petrogenetic models. Geophysical Research Letters 3, 249-252.

Dodge, T.H. 1934. The determination of optic angle with the universal stage. American Mineralogist 19, 62-75.

Eklund, O., Shebanov, A., Fröjdö, S., Yli-Kyyny, K. \& Andersson, U.B. 1996. A low-foliated ignimbrite related to the Åland rapakivi granite in SW Finland. Terra Nova 8, $548-557$.

Farmer, G.L. \& DePaolo, D.J. 1983. Origin of Mesozoic and Tertiary granite in the western U.S. and implications for pre-Mesozoic crustal structure. I. Nd and Sr isotopic studies in the geocline of the northern Great Basin. Journal of Geophysical Research 88, 3379-3401.

Faure, G. 2001. Origin of Igneous Rocks; The Isotopic Evidence. Springer-Verlag, Berlin, Heidelberg, New York, $501 \mathrm{p}$.

Gehrels, G., Rushmore, M., Woodsworth, G., Crawford, M., Andronicos, C., Hollister, L., Patchett, J., Ducea, M., Butler, R., Klepeis, K., Davidson, C., Friedman, R., Haggart, J., Mahoney, B., Crawford, W., Pearson, D. \& Girardi, J. 2009. U-Th-Pb geochronology of the Coast Mountains batholith in north-coastal British Columbia: Constraints on age and tectonic evolution. Geological Society of America Bulletin 121, 1341-1361.

Haapala, I. 1974. Some petrological and geochemical characteristics of rapakivi granite varieties associated with greisen-type Sn, Be, and W mineralization in the Eurajoki and Kymi areas, southern Finland. In: Štemprok, M. (Ed.), Metallization associated with acid magmatism I. Praha, Ústrední ústav geolgickÿ, pp. 159-169.

Haapala, I. 1977. Petrography and geochemistry of the Eurajoki stock, a rapakivi-granite complex with greisen-type mineralization in southwestern Finland. Geological Survey of Finland, Bulletin 286, 128 p.

Haapala, I. \& Rämö, O.T. 1990. Petrogenesis of the Proterozoic rapakivi granites of Finland. In: Stein, H.J. \& Hannah,
J.L. (Eds.), Ore-bearing granite systems; Petrogenesis and mineralizing processes. Geological Society of America Special Paper 246, 275-286.

Hackman, V. 1934. Das Rapakiwirandgebiet der gegend von Lappeenranta (Willmanstrand). Bulletin de la Commission Géologique de Finlande 106, 87 p.

Harju, S., Rämö, O.T., Mänttäri, I. \& Luttinen, A.V. 2010. The Taalikkala megaxenolith. In: Heinonen, A., Lukkari, S. \& Rämö, O.T. (Comps.), Guide to the IGCP-510 (Atype Granites and Related Rocks through Time) Field Trip, Southeastern Finland, August 14-18, 2010. Department of Geosciences and Geography C3, Helsinki University Print, Helsinki, pp. 22-25.

Heinonen, A.P., Rämö, O.T., Mänttäri, I., Johanson, B. \& Alviola, R. 2010a. Formation and fractionation of high$\mathrm{Al}$ tholeiitic magmas in the Ahvenisto rapakivi granitemassif-type anorthosite complex, southeastern Finland. Canadian Mineralogist 48, 969-990.

Heinonen, A.P., Andersen, T. \& Rämö, O.T. 2010b. Reevaluation of rapakivi petrogenesis: Source contrains from the Hf isotope composition of zircon in the rapakivi granites and associated mafic rocks of southern Finland. Journal of Petrology 51, 1687-1709.

Huhma, H. 1986. Sm-Nd, U-Pb and Pb-Pb isotopic evidence for the origin of the Early Proterozoic Svecokarelian crust in Finland. Geological Survey of Finland Bulletin 337, $48 \mathrm{p}$.

Kouvo, O. 1958. Radioactive age of some Finnish Precambrian minerals. Bulletin de la Comission Géologique de Finlande $182,70 \mathrm{p}$.

Krogh, T.E. 1973. A low-contamination method for hydrothermal decomposition of $\mathrm{U}$ and $\mathrm{Pb}$ for isotopic age determinations. Geochimica et Cosmochimica Acta 37, 485-494.

Krogh, T.E. 1982. Improved accuracy of U-Pb zircon ages by the creation of more concordant systems using an air abrasion technique. Geochimica et Cosmochimica Acta 46, 637-649.

Levchenkov, O.A., Bogdanov, Yu.B., Komarov, A.N., Yakovleva, S.Z. \& Makeev, A. F. 1998. Isotopic age of quartz porphyry from the Hogland Group. Doklady Earth Sciences 358, 511-516.

Ludwig, K.R. 1991. PbDat 1.21 for MS-dos: A computer program for IBM-PC Compatibles for processing raw $\mathrm{Pb}-$ U-Th isotope data. Version 1.07. U.S. Geological Survey, Open-File Report 88-542, 35 p.

Ludwig, K.R. 2003. Isoplot/Ex 3. A geochronological toolkit for Microsoft Excel. Berkeley Geochronology Center. Special publication No. 4.

Lukkari, S. 2007. Magmatic evolution of topaz-bearing granite stocks within the Wiborg rapakivi granite batholith. Publications of the Department of Geology D12, University of Helsinki, Helsinki, 29 p. (plus four article appendices) 
Müller, W., M. Shelley, Miller, P. \& Broude, S. 2009. Initial performance metrics of a new custom-designed ArF excimer LA-ICPMS system coupled to a two-volume laser-ablation cell. Journal of Analytical Atomic Spectrometry 24, 209-214.

Nebel, O., Scherer, E.E. \& Mezger, K. 2011. Evaluation of the ${ }^{87} \mathrm{Rb}$ decay constant by age comparison against the $\mathrm{U}-\mathrm{Pb}$ system. Earth and Planetary Science Letters 301, 1-8.

Neymark, L.A., Amelin, Yu.V. \& Larin, A.M. 1994. Pb-Nd-Sr isotopic constraints on the origin on the 1.54-1.56 Ga Salmi rapakivi granite-anorthosite batholith (Karelia, Russia). Haapala, I. \& Rämö, O.T. (Eds.), IGCP Project 315 Publication No. 12. Mineralogy and Petrology 50 (13), 173-194.

Pokki, J., Kohonen, J., Rämö, O.T. \& Andersen, T. 2013. The Suursaari conglomerate (SE Fennoscandian shield; Russia) - Indication of cratonic conditions and rapid reworking of quartz arenitic cover at the outset of the emplacement of the rapakivi granites at ca. $1.65 \mathrm{Ga}$. Precambrian Research 233, 132-143; doi: 10.1016/j.precamres.2013. 04.008

Rämö, O.T. 1991. Petrogenesis of the Proterozoic rapakivi granites and related basic rocks of southeastern Fennoscandia: $\mathrm{Nd}$ and $\mathrm{Pb}$ isotopic and general geochemical constraints. Geological Survey of Finland, Bulletin 355, $161 \mathrm{p}$.

Rämö, O.T. 2001. Isotopic composition of pyterlite in Vyborg (Viipuri), Wiborg batholith, Russia. Bulletin of the Geological Society of Finland 73, 111-115.

Rämö, O.T. \& Arponen, E. 2010. Anorthositic xenoliths in the Ylämaa area, east-central Wiborg batholith. In: Heinonen, A., Lukkari, S. \& Rämö, O.T. (Comps.), Guide to the IGCP-510 (A-type Granites and Related Rocks through Time) Field Trip, Southeastern Finland, August 14-18, 2010. Department of Geosciences and Geography C3, Helsinki University Print, Helsinki, pp. 26-27.

Rämö, O.T. \& Haapala, I. 1995. One hundred years of Rapakivi Granite. Mineralogy and Petrology 52, 129-185.

Rämö, O.T. \& Haapala, I. 2005. Rapakivi granites. In: Lehtinen, M., Nurmi, P.A. \& Rämö, O.T. (Eds.), Precambrian Geology of Finland - Key to the Evolution of the Fennoscandian shield. Developments in Precambrian Geology, Volume 14. Elsevier, Amsterdam, 553-562.

Rämö, O.T., Huhma, H. \& Kirs, J., 1996. Radiogenic isotopes of the Estonian and Latvian rapakivi granite suites: new data from the concealed Precambrian of the East European Craton. Precambrian Research 79, 209-226.

Rämö, O.T., Mänttäri, I., Huhma, H., Niin, M. \& Pokki, J. 2007. 1635 Ma Bimodal volcanism associated with the Wiborg rapakivi batholith (Suursaari, Gulf of Finland, Russia). In: Miller, J.A. \& Kisters, A.F.M. (Eds.), 6th International Hutton Symposium Abstract Volume \& Program Guide. Stellenbosch University, Stellenbosch, $174-175$.
Rämö, O.T., Turkki, V., Mänttäri, I., Larjamo, K., Karvonen, T. \& Pokki, J. 2010. Rapakivi granites and extrusive rocks in the archipelago of the Finnish Gulf. In: Heinonen, A., Lukkari, S. \& Rämö, O.T. (Comps.), Guide to the IGCP510 (A-type Granites and Related Rocks through Time) Field Trip, Southeastern Finland, August 14-18, 2010. Department of Geosciences and Geography C3, Helsinki University Print, Helsinki, 13-17.

Rämö, T. 1999. Sr isotopic composition of Finnish rapakivi granites: the Suomenniemi batholith. Bulletin of the Geological Society of Finland 71, 339-345.

Rankenburg, K., Lassiter, J.C. \& Brey, G. 2004. Origin of megacrysts in volcanic rocks of the Cameroon volcanic chain - constraints on magma genesis and crustal contamination. Contributions to Mineralogy and Petrology 147, 129-144.

Richard, P., Shimizu, N. \& Allègre, C. J. 1976. 143Nd/146Nd, a natural tracer: an application to oceanic basalts. Earth and Planetary Science Letters 31, 269-278.

Rowley, P.D, Nealey, L.D., Unruh, D.M., Snee, L.W., Mehnert, H.H., Anderson, R.E. \& Grommé, C.R. 1992. Stratigraphy of Miocene ash-flow tuffs in and near the Caliente caldera complex, southeastern Nevada and southwestern Utah. In: Scott, R.B. \& Swadley, W.C. (Eds.), Geologic studies in the Basin and Range-Colorado Plateau transition in southeastern Nevada, southwestern Utah, and Northwestern Arizona, 1992. U.S. Geological Survey Bulletin 2056, 47-88.

Salonsaari, P.T. 1995. Hybridization in the subvolcanic JaalaIitti complex and its petrogenetic relation to rapakivi granites and associated mafi c rocks of southeastern Finland. Bulletin of the Geological Society of Finland 67 (1b), 1-104.

Scaillet, B., Pichavant, M. \& Roux, J. 1995. Experimental crystallization of leucogranite magmas. Journal of Petrology 36, 663-705.

Sederholm, J.J. 1891. Ueber die finnländischen Rapakiwigesteine. Tschermak's Mineralogische und Petrographische Mittheilungen 12, 1-31.

Simonen, A. 1961. Olivine from rapakivi. Bulletin de la Commission Géologique de Finlande 196, 371-376.

Simonen, A. 1987. Kaakkois-Suomen rapakivimassiivin kartta-alueiden kallioperä. Summary: Pre-Quaternary rocks of the map-sheet areas of the rapakivi massif in SE Finland. Suomen geologinen kartta 1:100 000, Geological map of Finland 1:100 000. Geological Survey of Finland.

Simonen, A. \& Vorma, A. 1969. Amphibole and biotite from rapakivi. Bulletin de la Commission Géologique de Finlande 238, 28 p.

Stacey, J.S. \& Kramers, J.D. 1975. Approximation of terrestrial lead isotope evolution by a two-stage model. Earth and Planetary Science Letters 26, 207-221.

Suominen, V. 1991. The chronostratigraphy of SW Finland with special reference to the Postjotnian and Subjotnian 
diabases. Geological Survey of Finland, Bulletin 356.

Tröger, W.E., Bambauer, H.U., Taborszky, F. \& Trochim, H.D. 1979. Optical Determination of Rock-Forming Minerals. Part 1: Determinative Tables. Schweizerbart, Stuttgart, $188 \mathrm{p}$.

Turkki, V. 2005. Pyhtään Ristisaaren kallioperä ja sen tumma viborgiitti. M.Sc. thesis, Department of Geology, University of Helsinki. [in Finnish]

Vaasjoki, M. 1977. Rapakivi granites and other postorogenic rocks in Finland; Their age and the lead isotopic composition of certain associated galena mineralizations. Geological Survey of Finland Bulletin 294, 64 p.

Vaasjoki, M. 1996. Explanation to the geochronological map of southern Finland: The development of the continental crust with special reference to the Svecofennian orogeny. Geological Survey of Finland, Report of Investigation 135, $30 \mathrm{p}$.

Vaasjoki, M. \& Rämö, T. 1989. The Wiborg rapakivi batholith and associated rocks in sout-eastern Finland (Excursion A2), Symposium Precambrian Granitoids - Petrogenesis, geochemistry, metallogeny. Geological Survey of Finland, Guide 30, 32 p.

Vaasjoki, M., Rämö, O.T. \& Sakko, M. 1991. New U-Pb ages from the Wiborg rapakivi area: constraints on the temporal evolution of the rapakivi granite - anorthosite - diabase dike association of southeastern Finland. Precambrian Research 51, 227-243.

Vorma, A. 1971. Alkali feldspars of the Wiborg rapakivi massif in southeastern Finland. Bulletin de la Commission Géologique de Finlande 246, $72 \mathrm{p}$.

Vorma, A. 1976. On the petrochemistry of rapakivi granites with special reference to the Laitila massif, southwestern Finland. Geological Survey of Finland Bulletin 285, 98 p.

Wahl, W. 1925. Die Gesteine des wiborger Rapakiwigebietes. Fennia 45 (20), $127 \mathrm{p}$.

Wahl, W. 1947. A composite lava flow from Lounatkorkia, Hogland. Bulletin de la Commission Géologique de Finlande 140, 287-302.

Walker, B.A. \& Grunder, A. 2010. Crustal reworking during a long-lived magma pulse: 11 m.y. isotopic record from the Aucanquilcha volcanic cluster, central Andes. Abstract V14A-03 presented at 2010 the Fall Meeting, AGU, San Francisco, California, 13-17 December.

Wasserburg, G.J. 1963. Diffusion processes in lead-uranium systems. Journal of Geophysical Research 68, 4823-4846.

Welin, E., Vaasjoki, M. \& Suominen, V. 1983. Age differences between $\mathrm{Rb}-\mathrm{Sr}$ whole rock and U-Pb zircon ages of synand postorogenic Svecokarelian granitoids in Sottunga, SW Finland. Lithos 16, 297-305. 


\section{Appendix}

$\mathrm{U}-\mathrm{Pb}$ zircon data on the Ylijärvi spectrolite olivine leucogabbronorite (sample A119), Ylijärvi dark equigranular hornblende granite (A791), Muurikkala wiborgite (A29), and Hamina quartz-feldspar porphyry (A323) published by Suominen (1991; Table 10) were recalculated for this work by using data point-specific errors. The concordia diagram in Fig. Ala shows a combined discordia line based on Suominen's two zircon fractions (A, B) from A791 and three fractions (A through C) from A119. According to field observations (see Arponen et al., 2009), these rocks grade into each other over a distance of $\sim 10 \mathrm{~m}$ and are thus most probably coeval. Hence the combined discordia with an upper intercept of $1633 \pm 2$ Ma sets the crystallization age for both. The concordia diagram in Fig. A1b shows a discordia from the six zircon fractions (B through G) reported by Suominen (1991) for the Muurikkala wiborgite. The upper intercept age based on the five most concordant fractions $(\mathrm{B}, \mathrm{D}$ through $\mathrm{G}), 1632 \pm 2 \mathrm{Ma}$, is preferred as the crystallization age of the wiborgite. In Fig. A1c, a concordia diagram for ten zircon fractions (A through J) published by Suominen (1991) for the Hamina quartz-feldspar porphyry dike is shown. Discordia upper intercept age of the seven most concordant fractions (marked with red ellipses) is $1619 \pm 3 \mathrm{Ma}$ and is considered the best estimate of the emplacement age of the dike.
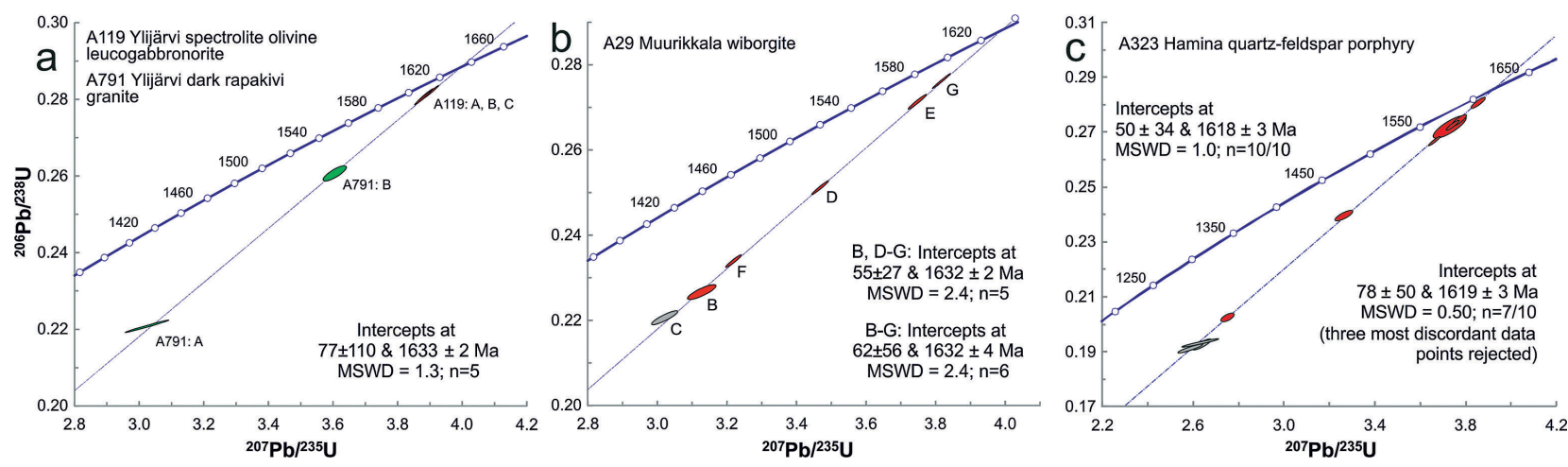

Fig. A1. U-Pb concordia diagrams for recalculated zircon isotope data (originally published by Suominen, 1991) on the Ylijärvi spectrolite olivine leucogabbronorite and dark rapakivi granite (a), Muurikkala wiborgite (b), and Hamina quartzfeldspar porphyry dike (c). 